\title{
A Modest Proposal to Abandon Strict Products Liability ${ }^{+}$
}

\author{
William Powers, Jr.*
}

In this article Professor William Powers, Jr. explains why products liability law is currently in disarray and presents a partial solution. To give some order to

products liability law, Professor Powers suggests doing away entirely with the doctrine of strict liability. The author asserts that although his plan sounds dramatic, it is really only a "modest proposal." Professor Powers feels the practice of maintaining a distinction between strict products liability and negligence has a pernicious effect on personal injury litigation, and that abandoning this distinction will have little impact on worthy cases.

\section{Introduction}

Current products liability law is a mess. Its foundation is flawed, its content is exceedingly complex, and its effect on personal injury litigation is pernicious. The primary culprit is the very hal mark of products liabilitylaw: the decision to distinguish product cases from other personal injury cases and subject them to strict products liability as a special theory of recovery, ${ }^{1}$ Courts should abandon this distinction and resolve product cases within the general framework of negligence law.

The foundation of strict products liability is flawed because the reasons courts have articulated to support strict liability for product injuries do not actually do so. Strict products liability rests on two implicit premises: (1) that product cases ate significantly different from other types of personal injury cases, and (2) that product cases are substantially homogeneous among themselves. In fact, product cases differ more among themselves than they differ from other personal injury cases. Theoretical arguments abound that support strict liability as a general approach to personal injury law. ${ }^{2}$ These arguments

+ Este artigo foi originalmente publicado na University of llinois Law Review, vol. 1991, número 3. Illinois, 1991. p. 639-682.

* Hines H. Baker and Thelma Kelley Baker Chair in Law. The University of Texas at Austin. B.A. 1967 University of California (Berkeley); J.D. 1973, Harvard Universify. I am grateful to David Robertson and Malcolm Wheeler for their extremely helpful comments.

By strict products liability $\mathrm{I}$ mean that body of law spawned by $\S 402 \mathrm{~A}$ of the Restatement (Second) of Torts (1964) and Greenman v. Yuba Power Prods., Inc., 377 P.2d 897 (Cal. 1963).

${ }^{2}$ See generally David A. Fischer \& Willam Powers, Jr. Products Liability 50-51 (1988); Guido Calabresi \& Jon T. Hirshoff, Toward a Test for Strict Liability in Torts, B1 Yale L.J. 1055 (1972) (favoring strict liability); David G. Owen, Rethinking the Policies of Strict Products Liability, 33 Vand L. Rev. 681 (1980); Richard A. Posner, A Theory of Negligence, 1 J. Legal Stud. 29 (1972) (favoring negligence); William C. Powers, Jr., Distinguishing Between Products and Services in Strict Liability, 62 N.C. L. Rev. 415, 423-28 (1984). 
fail to justify the existing structure of strict products liability, however, because strictproducts liability is neither a general approach to personal injury law nor a system of strict liability at all. Instead, it selectively applies to product cases special rules that, although supposedly different fromnegligence, fall far short of true strict liability. Most of the general arguments favoring strict liability fail to explain why productcases are special.

Strict products liability is exceedingly complex because courts have drawn arbitrary distinctions to maintain strictproducts liability and negligence as separate causes of action. Without well-articulated rationales for distinguishing product cases from other personal injury cases, judges have oscillated between general arguments for strict liability and general arguments for negligence, therebycreating a baroque system of doctrinal distinctions that defies rationalization. Bydrawing doctrinal distincrions in the absence of meaningful differences, the current approach to strict products liability fails to treat like cases alike.

Strict products liability also has a pernicious effecton personal injury litigation because itcan create havoc in multiparty litigation involving claims of bothnegligence and strict products liability. By distinguishing between product claims and other personal injury clains, strict products liability makes it difficult for a jury to adjudicate a multiparty, multitheory case as an integral unit.

Abandoning strict products liability is actually a more modest proposal than the terms "strict liability" and "negligence" suggest. In many cases, the underlying standards of liability for strict products liability and negligence differ only slightly. In cases involving warnings, virtually no difference exists between the two standards. Even in cases involving flaws and design defects, the difference between the two standards is less than it appears. Only in rare cases would the underlying standard of liability contained in my proposal keep a case from ajury when the case would have been submitted to the jury under strict products liability. Nevertheless, abandoning strict products liability as a separate cause of action would help significantly in rationalizing and simplifying personal injury litigation.

My proposal is modest in a second sense as well: it does not rely heavily on controversial judgments about the goals of tort law or about competing political claims of manufacturers and constumers - such as whether we face a "liability crisis." Of course, no change in a body of law is neutral in its effects. Consumers may condemn the proposal and manufacturers may applaud it. But my argument in favor of abandoningstrict products liability attempts to transcend this dispute. Myangument is that the current approach is not justified by the rationales its proponents use to support it and that its internal structure is so complex and arbitrary that it offends principles that most participants in the debate purport to accept. ${ }^{3}$

Specifically, my proposal is (1) to abandon strict products liability as a separate body of law, (2) to rely solely on negligence in product cases, but (3) to have a special rule within negligence to govern manufacturing defects. ${ }^{4}$ This special rule for mantuacturing defects might provide that a

\footnotetext{
${ }^{3}$ I do not mean to claim that "reason" dictates a certain structure of personal-injury law or that disputes about legal reform are not deeply imbedded in politics. I do claim that the current distinctions drawn by strict tort liability off political values that, contingently, transcend the current debate between the plaintiff's bar and the defense bar.

${ }^{4}$ As will become apparent throughout the article, manufacturing defects do present special problems that call for a special rule to help plaintiffs. The warranty provisions of Article 2 of the Uniform Commercial Code also govern product cases. See U.C.C. $\S \S 2-313,2-314,2-315, \& 2-715(2)(b)(1978)$. Although most of the analysis in this article addresses the distinction between strict products liability and negligence, in some states a solution to the problem would also require legislative action to withdraw parts of Article 2 from personal injury cases.
} 
manufacturer's violation of its own specifications raises a permissive inference of negligence, meaning that a court could not direct a verdict against a plaintiff for failing to prove what caused the flaw. It might provide that a manufacturer's violation of its own specifications raises a presumption of negligence, rebuttable only by a defendant's own evidence of reasonable care. Or, drawing on cases involving violations of statutes, it might provide that a manufacturer's violation of its own specifications constitutes negligence per se, irrespective of the evidence a defendant might martial to the contrary. ${ }^{5}$

The argument proceeds as follows. Part II argues that product cases do not form a distinct, integral group when judged against the policies that strict products liability purports

\begin{abstract}
${ }^{5}$ One might object that this proposal merely keeps strict products liability for flaws under the rubric of negligence. In one sense, this is true. But as we shalt see later, the rubric itself can be important. See infra notes 77-131 and accompanying text. Moreover, negligence already has other "pockets" of strict liability. It is sufficiently flexible to accommodate special, strict liability treatment of manufacturing defects without giving special treatment to design defects and warnings.Courts often evaluate the reasonableness of a defendant's conduct within a narrow context. A surgeon who slips with a scalpel or sews a sponge in a patient cannot nomally claim that his procedures prevent these accidents in al! but a very few cases. A motorist who changes lanes without looking may not escape liability merely because his driving habits permit this to happen only rarely. Similarly, a court could conclude that a manufacturer's deviation from its own specifications constitutes negligence, even though the manufacturer's quality control procedures usually prevent this from happening. Doing so may represent a deviation from fault, but no more so than in the case of the surgeon or the motorist. See William Powers, Jr. On Positive Theories of Tort Law, 66 TEX. L. REV. 191, 205-07 (1987) (reviewing WILLIAM M. LANDES \& RICHARD A. POSNER, THE ECONOMIC STRUCTURE OF TORT LAW (1987)) [hereinafter On Positive Theories]; William C. Powers, Jr., The Persistence of Fault in Products Liability, 61 TEX. L. REV. 777, 813-15 (1983) (hereinafter The Persistence of Faulty. Landes and Posner have recognized this flexible nature of negligence law. WILLIAM M. LANDES \& RICHARD A. POSNER, THE ECONOMIC STRUCTURE OF TORT LAW 54-84 (1987). Following Diamond, they recognize that when an individual selects a certain level of care, he cannot know with precision how his decision will affect his performance. Peter A. Diamond, Single Activity Accidents, 3 J. LEGAL STUD. 107, 124 (1974). At best, he can predict only that by selecting a certain level of care, his performance will fail within a range of expected results. Thus, if the median of his expected performance is optimal, he can anticioate that he will occasionally perform suboptimally. A driver who has carefully formed a habit of looking over his shoulder before changing lanes should expect that he will nevertheless sometimes inadvertently fall to do so. A surgeon who carefully studies and practices technique, who exercises, who abstains from alcohol, and who gets pienty of rest should nevertheless expect that he will have occasional suboptimal performances. The stochastic nature of care raises an important and seldom recognized problem for apolying negligence to specific cases: Should we apply the cost-beneitt analysis of the Leamed Hand formula to global or local conduct of the defendant? See United States v. Carroll Towing Co., 159 F.2d 169, 173 (2d Cir. 1947). For example, should the issue in a surgical malpractice case be whether the surgeon's local conduct during the surgery was optimal (that is, whether he slipped with the scalpei) or whether his global training and preparation were optimal? (Of course, if a court applies the negligence standard globally, it should recognize that the optimal selection of preparatory care itself should account for the stochastic nature of care: the surgeon should choose a level of preparatory care that recognizes that his actual performance will vary from the median in individual cases.) A global application of negligence would constitute an actual negligence system. Limiting the jury's range of inquiry constitutes a pocket of strict liability within negligence law, in practice, however, all issues of negligence are local to some degree. Courts do not, in fact, permit a doctor to justify slips with a scalpel by allowing the doctor to argue that he has led a life that minimizes slips.Competing liability rules fall on a spectrum between giobal negligence (which evaluates the totality of the defendant's conduct relative to the risk) and local, strict liability (which evaluates oniy whether the defendant caused the plaintiffs injury). On this continuum, ordinary negligence is more global than strict tor liability-oecause it examines a wider range of the defendant's behavior-but even negligence has aspects of strict liability. Good reasons exist for a "pocket" of strict liability within negligence law in cases involving manufacturing defects, because proof of negligence may be too difficult. Similar reasons do not exist for having a similar "pockef" of strict liability for cases involving design defects and warnings. And even in cases involving manufacturing defects, there is no good reason for maintaining an entirely separaie cause of action.
\end{abstract}


to advance. Part III focuses on the definition of defect within strict products liability. It argues that a shift from strict liability to negligence would represent only a minimal shift in the underlying standard of liability, and it highlights the indefensible lines courts have drawn in an attempt to maintain the distinction between defectiveness and negligence. Part IV addresses the pernicious effect the distinction between strict products liability and negligence has had on courts' treatment of certain "collateral" doctrines, such as causation and plaintiff-conduct defenses. Part V treats problems courts have faced applying two distinct theories of liability in one lawsuit.

\section{Strict Products Liability Is Not Supported by Its Articulated Rationales}

A decision to apply strict products liability to product cases but not other personal injury cases requires at least a plausible underlying rationale that explains why product cases form a distinct, integral group. Courts have not articulated such a rationale, which helps explain why they have floundered so badly when addressing specific problems within strict products liability.

Arguments abound dealing with the general merits of strict liability and negligence. Some rely on economic theory ${ }^{6}$, others rely on concepts of distributive justice? and still others focus on whether we suffer from a "liability crisis." Both sides of the debate make plausible claims. Most of us, in fact, are somewhat ambivalent about the competing claims of strict liability and negligence. We are attracted to the claim that people who cause injuries should compensate their victims, but we are simultaneously attracted to the claim that individuals should not be forced to pay compensation unless their conduct was blameworthy. Personal injury law can be usefully viewed as a set of compromises between these two competing approaches. ${ }^{9}$ Thus, the internal body of negligence law has pockets of strict liability, such as the objective standard of negligence, ${ }^{10}$ and strict products liability is infused with concepts of negligence. "

The fact that tort law is an amalgam of strict liability and negligence doctrines should be neither surprising nor troubling. It is unreasonable to think that one simple principle can alone govern all disputes in a given area of law. Even if courts resolve a debate between competing principles in a broad area of law-such as by adopting negligence as a general approach to personal injury law-they nevertheless will be faced with continual reprises of the debate when addressing details of doctrine. ${ }^{12}$ Thus, it is not

\footnotetext{
${ }^{6}$ See Calabresi \& Hirschoff, supra note 2; Posner, supra note 2.

${ }^{7}$ See George P. Fletcher, Faimess and Utility in Tort Theory, 85 Harv. L. Rev. 537 (1972).

\& See Peter W. Huber, Liability: The Legal Revolution And Its Consequences (1988).

${ }^{2}$ This is not the only dichotomy that is useful to understanding tort law. For example, tort law sometimes applies preexisting entitlements and sometimes anaiyzes cases with an ex post evaluation of "proper" conduct. Tort law also sometimes applies "liability" rules and sometimes applies "property" ruies. See Guido Calabresi \& A. Douglas Malamed, Property Ru1es, Liability Ruies, and Inalienability: One View of the Cathedral, 85 Harv. L. Rev. 1089, 1106-10 (1972). The dichotomy between strict liabllity and negligence is important here because it is the supposed halmark of strict products liability.

to See LANDES \& POSNER, supra note 5, at 73; Dlamond, supra note 5.

1 See infra notes $48-75$ and accompanying text.

12 See J.M. Balkin, Nested Oppositions, 99 Yale L.J. 1669 (1990).
} 
surprising and should not be intrinsically problematic for a court that has adopted negligence as a general approach to personal injury law to defer nevertheless to the attractiveness of strict liability when adopting an objective standard to define negligence. Consequently, the mere fact that courts purport to apply strict liability to product cases within a system that otherwise uses negligence does not ipso facto condemn strict products liability.

Nevertheless, courts still must justify the particular mix of strict liability and negligence they have chosen to adopt. This requires a showing that the amalgam of negligence and strict liability has at least minimal coherence and integrity. ${ }^{13}$ It would not be appropriate to apply strict liability on Tuesdays and Thursdays and negligence on Mondays, Wednesdays, and Fridays. Courts should have reasons for deferring to the attraction of strict liability in some circumstances but to the attraction of negligence in others. In short, courts should justify why product cases are treated differently. They have not done so. ${ }^{14}$

With one exception, ${ }^{15}$ arguments purporting to support strict products liability have the common defect of proving too much. Although these arguments are marshalled to support the selective application of strict liability to products, their breadth makes them applicable with equal force to other personal injury cases. This weakens them as justifications for the application of strict liability only to product cases. Moreover, even if these arguments did support selective applications of true strict liability, they do not support actual products liability law, which is based on defectiveness. An adequate justification for the current scheme of strict products liability would support the selective application of liability, based on defectiveness, to product injuries. With one exception, the rationales advanced to support strict products liability do not do so, and the exception fails to justify strict products liability for other reasons.

Courts have relied on various rationales to support strict products liability. ${ }^{16}$ Comment c to Restatement (Second) of Torts $\$ 402 \mathrm{~A}$ (1964) suggests several rationales. It states:

On whatever theory, the justification for strict liability has been said to be that the seller, by marketing his product for use and consumption, has undertaken and assumed a special responsibility toward any member of the consuming public who may be injured by it; that the public has the right to and does expect, in the case of products which it needs

\footnotetext{
3a See Ronald Dworkin, Law's Empire 176-224 (1986). It may not be possible to rationalize all law or even large portions of law. Some distinctions law draws may be nothing more than reflections of historical or political compromises that do not reflect values that transcend the distinction. It shouid nevertheless be a goal of law to be coherent in smaller areas. The fallure of a distinction to reflect any principled difference should at least count against the distinction.

${ }_{14}$ See Malcoim Wheeler, The Need for Narrow Tort Reform: Abolishing Strict Product Liability, in Product Liability Reform: Debating the Issues (Kenneth Chilton ed., 1990).

${ }_{15}$ See infra text accompanying notes 25-35. (3) helpless consumers are forced to rely on manufacturers for product safety; (4) product sellers are in a better position to spread the risk of loss; and (5) product sellers can better afford to bear the loss of product injuries. Courts have added to this list. I have discussed these rationales in William Powers, Jr., Texas Products Liability Law $\S 4.031$ (1986); Power supra note 2, at 423-28.
} 
and for which it is forced to rely upon the seller, that reputable sellers will stand behind their goods; that public policy demands that the burden of accidental injuries caused by products intended for consumption be placed upon those who market them, and be treated as a cost of production against which liability insurance can be obtained; and that a consumer of such products is entitled to maximum protection at the hands of someone, and the proper persons to afford it are those who market the products.

This passage is somewhat vague, but is suggests at least five separate rationales for strict liability in product cases:

(1) the product seller, by its position in the marketing chain, has a special responsibility for product safety;

\section{(2) consumers expect safe products;}

One rationale for strict products liability is that it promotes product safety by requiring manufacturers to bear accident costs, thus giving manufacturers an incentive to produce safer products. ${ }^{17}$ This argument is controversial even on its own terms. It is debatable, both analytically and empirically, whether strict liability increases product safety, much less whether it tends to optimize product safety. ${ }^{13}$ More important for the present inquiry, however, is that this argument fails to distinguish between product injuries and other personal injuries. Strict liability also could be used to transform the cost of

\footnotetext{
${ }^{17}$ See. e.g., Turner v. General Motors Corp., 584 S.W.2d 844 (Tex. 1979) (Campbell, J., concurring); Hoven v. Kelble, 256 N.W.2d 379 (Wis. 1977); Richard A. Epstein, Products Liability: The Gathering Storm, Regulation, Sept.-Oct. 1977, at 15, 19-20; John Riper, Note, Strict Liability in Hybrid Cases, 32 Stan. L. Rev. 391,393 (1980).

is Strictty speaking, "safer" products should not be the goal. Any product can be made safer by changing its design, but the alteration might in turn make the product unduly expensive or otherwise detract from its utility. The goal should be for manufacturers to design products with an appropriate or optimal level of safety, and this depends on incentives for both manufacturers and consumers. Theoretically, negligence coupled with the defense of contributory negligence provides incentives that tend to optimize safety, while strict liability without contributory negligence does not. See, e.g., John P. Brown, Toward an Economic Theory of Liabllity, 2 J. Legal. Stud. 323, 338-43 (1973); Epstein, supra note 17, at 19-20; Richard A. Posner, Strict Liability: A Comment, 2 J. Legal Stud. 205, 209 (1973). Of course, both consumers and manufacturers have incentives for safety other than legal rides, a fact which might justify results that contradict theoretical models, even if the goal were to optimize safety. The practical impact of strict liability on product safety is unclear. As Judge Posner has noted, "the question is at bottom empirical, and the empirical work has not been done." Id. at 212. The existing empirical evidence does not reflect a consensus. See William $C$. Whitford, Comment on a Theory of the Consumer Product Warranty, 90 Yale L.J. 1297, 1348 (1981) (suggesting that strict liability might reduce product safety); Michael J. Wisdom, Note, An Empirical Study of the Magnuson-Moss Warranty Act, 31 Stan. L. Rev. 1117, 1137-46 (1979). Moreover, it is not implausible to attribute increases in product safety to consumer pressure, direct governmental regulation, or increased litigation that might have occurred even under a negligence theory, rather than to the commonmlaw adoption of strict products liability.
} 
automobile accidents into a cost of driving, thereby providing an incentive for safety. ${ }^{9}$ Incentives for safety might support strict liability generally (depending on the empirical evidence), but they do not explain the selective application of strict liability to product injuries. ${ }^{20}$

A second common rationale for strict products liability is that it helps internalize accident costs into the price of products, thereby spreading a victim's loss among an entire group of consumers. ${ }^{21}$ Even if this is a desirable goal, which is itself controversial, ${ }^{22}$ it is not a goal that is specific to product injuries. ${ }^{23}$ Strict liability could also spread losses from nonproduct accidents. For example, losses from automobile accidents that are not currently covered by negkigence could be spread through strict liability and nearly universal liability insurance. ${ }^{24}$ Indeed, losses from disease and natural disaster seem to be as worthy of spreading as losses from product injuries, solely from the perspective of spreading risks. ${ }^{25}$

t9 We might distinguish product cases from nonproduct cases on the basis that a liability rule has less impact on product manufacturers than on nomproduct tort-feasors. In transactions that are subject to market forces, we might be less concerned with an allocative inefficiency created by a liability rule because the parties can bargain their way back to an efficient resilt. For example, entitlements given to real properly owners permit thern to use their land frivolously, but they "pay" the price of foregoing a sale or rental at a value reflecting the more efficient use. To the extent that strict liability is theoretically inefficient, it might be more tolerable in product cases in which a market can mitigate the inefficiency. The absence of a market among strangers prevents a similar mitigation of inefficiency in automobile accidents. Consequently, we might insist on a theoretically more efficient/liability rule, such as negligence. See generally R.H. Coase, The Problem of Social Cost, 3 J:L. \& Econ. 1 (1960); William C. Powers, Jr., A Methodological Perspective on the Duty to Act, 57 Tex. L. Rev. 523, 529 \& n.21 (1979) (reviewing Marshall S. Shapo, The Duty to Act: Tort Law, Power, \& Public Policy (1977)). No court has relied on this distinction, possibly because the actual impact of liability roles and markets on behavior is too uncertain, regardless of the theoretical models.

${ }^{20}$ A distinction between product injuries and other personal injuries might be that commercial defendants are more susceptible to influence by economic incentives than are individuals. But this rationale would be applicable to all injuries caused by commercial defendants, not just to injuries caused by products.

${ }^{24}$ See, e.g., Helene Curtis Indus., Inc. v. Prutt, 385 F.2d 841, 862 (5th Cir. 1967), cert. denied, 391 U.S. 913 (1968); Escola v. Coca Cola Bottling Co. of Fresno, 150 P.2d 436, 44.1 (Cal. 1944) (Traynor. J., concurring); Turner, 584 S.W.2d at 853-54 (Campbell, J., concurring); Davis v. Gibson Prods. Co., 505 S.W.2d 682, 690 (Tex. Civ. App. 1973), writ refused, 513 S.W.2d 4 (Tex. 1974); Hoven, 256 N.W.2d at 391; Epstein, supra note 17, at 19-20. This rationale often parades under the banner of the defendant's financial ability to bear the loss, although ability to bear the loss might also refer to considerations of wealth distribution. See Seely v. White Motor Co., 403 P.2d 145, 151 (Cal. 1965); Phipps v. General Motors Corp., 363 A.2d 955, 958 (Md. 1976).

22 See, e.g., Markle v. Mutholland's, Inc., 509 P.2d 529, 546 (Or. 1973) (en banc) (Bryson, J., dissenting); Howard C. Klemme, The Enterprise Liability Theory of Torts, 47 U. CoLo. L. Rev. 153, 191-93 (1976). ${ }^{23}$ See, e.g., Epstein, supra note 17, at 19-20. indeed, some courts have declined to recognize this as a significant policy underlying strict products liability. See e.g., Brody v. Overlook Hosp., 317 A.2d 392, 398 (N.J. Super. Ct. App. Div. 1974), aff'd per curiam, 332 A.2d 596 (N.J. 1975).

${ }^{24}$ Strict liability for product injuries spreads bases by raising a product's price. Strict liability for automobile accidents would spread losses by raising liability insurance rates. The current system of automobile insurance spreads bases only if they are caused by negligent drivers, except for the meager level of first-party coverage. Another argument for giving product injuries special treatment is that, urilike victims of automobile injuries, victims of product injuries do not have insurance. Consequently, they need another mechanism for spreading losses. One response to this argument is that people could insure against product injuries. Moreover, people typically do not insure againsi most types of loss through first party automobile insurance.

${ }^{25}$ See Epstein, supra note 17, at 19-20. 
Equally telling in the present context is that, although the argument for spreading risks is as powerful for injuries caused by nondefective products, ${ }^{26}$ courts uniformly deny recovery in these cases. Although the rhetoric of risk spreading is often used to support strict products liability for victims of defective products, it does not actually justify the selective use of strict liability for victims of defective products in the context of a system that declines to use strict liability for other injuries, including injuries from nondefective products.

A third rationale for strict products liability reflects strict products liability's warranty heritage: defective products frustrate consumer expectations. ${ }^{27}$ Especially in early cases, courts relied on consumer expectations created by general assurances of safety and quality that were found in advertising or that were inherent in the mere fact that a product was placed on the market. ${ }^{28}$ The emphasis on consumer expectations has waned, however, both as a test of defectiveness and as a reason for liability. ${ }^{29}$ One problem with this rationale is that it is difficult to ascertain consumer expectations in all but the simplest cases. ${ }^{30}$ Moreover, consumer expectations fail to explain why courts should treat products differently than services. ${ }^{31}$ Consequent $y$, courts have been willing to free products liability from its warranty moorings.

I will have more to say about consumer expectations when I address defectiveness in Part UI. The point there will be that in most product cases - especially cases not involving manufacturing defects - consumer expectations do not provide a meaningful test of defect and therefore do not provide an adequate ground for strict products liability. In some cases, however, consumer expectations may be sufficiently concrete to support liability, and to the extent that the manufacturer created these expectations, they provide a reason for distinguishing product cases. Though defendants in other personal injury cases may also create expectations-such as drivers creating an expectation of following the rules of the road-expectations created in a sales situation may warrant special treatment.

Nevertheless, consumer expectations have limitations as a ground for strict products liability. In most cases, consumer expectations are too vague; in those in which they are not, strict products liability is not a necessary response. Consumer expectations are likely to be well formed only in cases involving manufacturing defects or in cases involving explicit or implicit representations by manufacturers. I already have stated that negligence law can accommodate cases involving manufacturing defects. Similarly, the law of

${ }^{26} \mathrm{Id}$.

${ }^{27}$ See Restatementi (Second) of Torts $\$ 402 \mathrm{~A} \mathrm{cmt.} \mathrm{m} \mathrm{(1964);} \mathrm{Marshall} \mathrm{S.} \mathrm{Shapo,} \mathrm{A} \mathrm{Representational}$ Theory of Consumer Protection: Doctrine, Function and Legal Liability for Product Disappointment , 60 Va. L. Rev. 1109 (1974); Riper, supra note 17.

${ }_{28}$ See Greenman v. Yuba Power Prods., Inc, 377 P.2d 897 (Cal, 1963); see also Heaton v. Ford Motor Co., 435 P.2d 806 (Or. 1967): McCown v. International Harvester Co., 342 A.2d 381 (Pa. 1975); Salvador v. Atlantic Steel Boiler Co., 319 A.2d 903 (Pa. 1974); Henderson V. Ford Motor Co., 519 S.W.2d 87 (Tex. 1974); Vincer v. Esther Williams All-Aluminum Swimming Pool Co., 230 N.W.2d 794 (Wis. 1975).

29 See. e.g., Turner v. General Motors Corp., 584 S.W.2d 844 (Tex. 1979).

so See The Persistence of Fault: supra note 5, at 794-97.

31 See Powers, supra note 2. 
warrancy or misrepresentation adequately can address cases involving real representations, either explicit or implicit. These solutions do not have as a by-product the problems inherent in maintaining strict products liability as a separate cause of action-that is, problems created by treating all product cases separately, simply because they involve products.

A fourth rationale for strict products liability is that it places the burden of injuries on manufacturers who are in a better position to prevent injury, "rather than [on] the injured persons who are powerless to protect themselves." 32 "This rationale is itself controversial, ${ }^{33}$ but even more important, it does not distinguish product injuries from other types of personal injuries. Victims of automobile accidents are often "powerless" to protect themselves, and the tort-feasor is in a better position to prevent the loss. Indeed, in consumer transactions the victim often has had at least the opportunity to select the manufacturer, a choice not usually given to the victim of an automobile accident.

A fifth rationale of strict products liability is that faimess requires a manufacturer to compensate victims because the manufacturer deliberately has imposed risks on consumers for its own benefit. ${ }^{34}$ Similar arguments have been used to explain tort liability generally, ${ }^{35}$ and therein lies its weakness as a justification for special treatment of product injuries. Motorists deliberately impose risks on pedestrians for the motorists' own benefit, yet we do not impose liability on motorists absent proof of negligence, ${ }^{36}$

A final tationale for strict products liability is that plaintiffs face an unduly difficult burden of proving specific acts of negligence in product cases. ${ }^{37}$ The "proof" rationale for strict products liability does not necessarily deny that fault is the underlying motivation for liability. Instead, it posits that negligence is a common cause of defective products and that a plaintiff's inability to prove negligence is more likely to be a consequence of the

\footnotetext{
${ }^{32}$ Yuba Power, 377 P.2d at 901; see also Tumer, 584 S.W.2d at $853-54$ (Campbell, J., concurring).

${ }^{33}$ See, e.g., Kemme, supra note 22, at 191 n.107.

${ }^{34}$ See Thornas A. Cowan, Some Policy Bases of Products Liability, 17 Stan. L. Rev. 1077, 1087-92 (1965).

${ }^{35}$ See Fletcher, supra note 7. But see Coase, supra note 19; Posner, supra note 2 (arguing that the alleged tort-feasor no more imposes risks on the victim than vice versa).

${ }^{36}$ Indeed, this rationale provides a stronger argument for strict liability in accidents among strangers than it does in many product cases. Because a manufacturer's liability usually is passed on to consumers, the risks and benefits of a liability rule are distributed roughly reciprocally. This is not necessarily true for accidents among strangers. We should not make too much of this distinction, however, because in the most common form of accidents among strangers-automobile accidents - the rate structure of automobile insurance tends toward reciprocity. Lack of reciprocity is a problem in accidents between drivers and pedestrians, but it is similarly a problem in product injuries involving bystanders. Nevertheless, if the distinction has any validity, it argues for strict liability in nonproduct cases, not in product cases.

${ }^{37}$ See, e.g., La Rossa v. Scientific Design Co., 402 F.2d 937, 942 (3d Cir. 1968); Escola v. Coca Cola Bottling Co. of Fresno, 150 P2d 436, 441 (Cal. 1944) (Traynor, J., concurring); Phipps v. General Motor Corp., 363 A.2d 955, 958 (Md. 1976); Pittsburg Coca-Cola Bottling Works v. Ponder, 443 S.W.2d 546, 54849 (Tex. 1969); Jacobs v. Technical Chem. Co., 472 S.W.2d 191, 197-98 (Tex. Civ. App. 1971), rev'd on the grounds, 480 S.W.2d 602 (Tex. 1972); Hoven v. Kelble, 256 N.W.2d 379, 391 (Wis. 1977); Cowan, supra note 34, at 1087; W. Page Keeton, Products Liability-Problems Pertaining to Proof of Negligence, 19 Sw. L.J. 26-39 (1965); John E. Montgomery \& David G. Owen, Reflections on the theory and Administration of Strict Tort Liaibility for Defective Products, 27 S.C. L. Rev. 803, 809 (1976); Riper, supra note 17, at 395.
} 
difficulty of proof than of the manufacturer's actual freedom from negligence. ${ }^{38}$ Proving negligence is difficult in any personal injury case. Witnesses might give conflicting accounts of the events, and the mechanism of the injury might have been destroyed in the accident. The problem of proof is more acute in product cases, however, because the alleged negligence normally occurred at a place controlled by the defendant and at a time before the plaintiff had any connection with the defendant or the product. These conditions sometimes exist in nonproduct cases, such as when a motorist fails to maintain his brakes adequately, ${ }^{39}$ but product injuries present this problem more acutely than other types of injuries. ${ }^{40}$ Consequently, courts can make a principled argument for relieving plaintiffs of the burden of proving negligence in product cases while requiring proof of negligence in other types of personal injury cases.

The "proof" rationale is especially attractive because it harmonizes specific internal features of strict products liability in a way that the other rationales do not. For example, the "unavoidable danger" ${ }^{41}$ and "state-of-the-art" "defenses" are grounded implicitly on a judgment that we could not have expected the manufacturer to have made the product safer. (Risk spreading does not explain these defenses, because these risks are as worthy of spreading as any other risks.) Notwithstanding the normal inference of negligence from defectiveness, we are not convinced that a manufacturer was negligent in cases involving

\begin{abstract}
${ }^{39}$ Other argument might be constructed to support strict tort liability. For example, strict products liablity might rest on an argument similar to unit pricing in supermarkets. If accident costs are reflected in a product's price, they are more visible to consumers, although the actual cost of the product (including risk) is unchanged. The increased visibility of actual product costs might heip consumers shop comparatively and make better allocative decisions. The problem with this argument is that, like the risk-spreading argument, it is incompatible with the requirement of defectiveness. Of course, this could be remedied by dropping the requirement of defectiveness, but that solution is very unlikely. Moreover, no court has actually relied on this argument.Another possible rationale is that strict tort liability avoids technical obstacles (such as timely notice) that plaintiffs face under the Uniform Commercial Code. See Greenman v. Yuba Power Prods., Inc., 377 P.2d 897, 899 (Cal. 1963). It is difficult to take this arguiment seriously, however, because the obvious solution is to amend the UCC. Furthermore, this rationale does not itself explain the existence of implied warranties in the Code. Sometimes we will find "smoke without fire," but experience and intuition might suggest that defectiveness implies negligence more often than not, even when the plaintiff cannot prove it. The plaintiff's failure might simply be due to the acute problems of proof presented by a product injury.
\end{abstract}

${ }^{39}$ Indeed, a plaintiff's inability to gather evidence sometimes triggers the doctrine of res ipsa loquitur, and in this sense strict products liability is similar to res ipsa loquitur. See Cowan, supra note 34, at 1094; cf. Siegler v. Kuhiman, 502 P.2d 1181, 1184-87 (Wash. 1973) (comparing common law strict liability to res ipsa loquitur).

${ }^{40}$ See. e.g., La Rossa, 402 F.2d at 942; Escola, 150 P.2d at 441 (Traynor, J., concurring); Phipps, 363 A.2d at 958; Pittsburg Coca-Cola, 443 S.W.2d at 548.49; Jacobs, 472 S.W.2d at 197-98;

Hoven, 256 N.W.2d at 391; Cowan, supra note 34, at 1087; Keeton, supra note 37, at 26-39; Montgomery \& Owen, supra note 37, at 809; Riper, supra note 17, at 395.

¿1 See, e.g., Brody v. Overlook Hosp., 317 A.2d 392, 397 (N.J. Super. Ct. App. Div. 1974), aff'd per curiam, 332 A.2d 596 (N.J. 1975). But see Cunningham v. MacNeal Memoria! Hosp., 47 fll. 2d 443, 453-56, 266 N.E.2d 897, 902-03 (1970).

${ }^{42}$ See. e.g., Bruce v. Martin-Marietta Corp., 544 F.2d 442, 447 (10th Cir. 1976); Beshada v. JohnsManville Prods. Corp., 447 A.2d 539, 544-49 (N.J. 1982); Boatland of Houston, Inc, v. Bailey, 609 S.W.2d 743, 746 (Tex. 1980). 
"unavoidable dangers" or "state-of-the-art" technology. The plaintiff's failure to prove negligence in these cases is not due to mere problems of proof. ${ }^{43}$

Unlike some other rationales, the proof rationale is also consistent with coutts' refusal to compensate victims of nondefective products. A defect raises a much stronger inference of negligence than does a mere injury. Moreover, while defectiveness is not always easy to prove, a plaintiff at least has contemporaneous access to the product itself, mitigating the special problems of proving specific acts of negligence in the manufacturing process. ${ }^{44}$ The proof rationale does not explain the liability of retalers who have not themselves been negligent. The liability of retalers is due in part to the historical legacy of warranty law and to the difficulty of obtaining local jurisdiction over a manufacturer. Long arm jurisdiction has undermined this rationale; the liability of tetailers is primarily vestigial.

The proof rationale is important not because it necessarily tepresents good policy, but because it is the one rationale that offers at least a plausible reason to distinguish product injuries from other personal injuries. For this reason, I will give it close attention throughout the article. Nevertheless, it has problems of its own as a foundation for strict products liability. First, it may have been a stronger rationale when courts first adopted strict products liability than it is today. Discovery techniques have improved, the plaintiffs' bar has become more sophisticated, and trial courts may be more willing to permit juries to draw inferences of negligence from circumstantial evidence..$^{45}$

Second, the proof rationale applies only to manufacturing defects (flaws). It does not apply to design defects or warnings. In a case involving a manufacturing defect, the offending product is different from other products in the line. We may never know why. But a design defect or waming is common to all products in the line. They were the result

${ }^{43}$ See Overlook Hosp., 317 A.20 at 397 . The "proof" rationale can be generalized into an argument that includes other concerns about the litigation process. Requiring plaintiffs to prove negligence has the risk of creating too many false negatives, that is, cases in which a plaintiff is unable to prove negligence even though the defendant actually was negligent. But it also consumes resources, including the time and effort of parties and the court. The uncertainty of the outcome also diffuses the regulatory effect this body of law has on persons whose conduct we want to influence. It may be that these "administrative" considerations are more important in product cases than other personal injury cases.Landes and Posner rely on concerns of this sort to explain strict liability for products based on long-term economic efficiency. Landes \& Posner, supra note 5 , at 273-311; see also On Positive Theories, supra note 5 , at $205-11$. Ultimately, the force of this argument depends on empirical data, but three initial observations are in order. First, courts have not, in fact, relied on an expanded "administrative" argument of this sort. Second, it is not at all clear why these "administrative" concems (other than the fear of false negatives) shouid be more acute in product case. Third and most important, they depend mainly on differences between negligence and true strict liability, which, as a true entitlement system, would be more predictable and easier to apply. See Powers, supra note 19, at 534-36. But as we shall see in the next part, strict products liablity is not a system of true strict liability. By depending on a jury finding of defectiveness, it lacks the formal clarity necessary to reap the administrative advantages this argument envisions.

${ }_{45}$ See, e.g., Yates v. Chappell, 139 S.E.2d 728 (N.C. 1965). Of course, each of these claims could profit from empirical work, which, to my knowledge, has not been done. 
of design decisions that are as susceptible to documentation and discovery as any other business decision. While the proof rationale distinguishes cases involving manufacturing defects from other personal injury cases, it also distinguishes them from other product cases. Third, to the extent the proof rationale does support special treatment of cases involving flaws, permitting the jury to draw an inference of negligence from the existence of a flaw, creating a presumption of negligence, or holding that flaws constitute negligence per se can all remedy proof problems. Doing so would keep product cases within the framework of negligence law and avoid certain problems that I will address below. ${ }^{46}$ The proof rationale does offer some support for distinguishing some product cases-cases involving manufacturing defects - from other personal injury cases. But that problem is so easily remedied within negligence law that it does not, on balance, provide an adequate basis for giving special treatment to all product cases under an independent cause of action.

In short, the rationales courts have offered to justify strict products liability do not adequately support a distinction between product cases and other personal injury cases. The proof rationale and consumer expectations offer some support for distinguishing some product cases from other personal injury cases, but they do not apply to most product cases as an integral group, and they can be satisfied by other means. ${ }^{43}$

${ }^{46}$ See infra notes $48-131$ and accompanying text.

47 A different type of argument, however, might be advanced in favor of strict products liability. Why should we make such a fuss about consistency? We would prefer, the proponent might argue, to apply strict liability (or some other version of expanded liability) to al personal injury cases. But as a political matter, we have been able to prevail only in product cases. At a deep level, law can never be perfectly rational, so we should accept this distinction as one of many inevitable, arbitrary compromises among social interests. After all, half a loaf is better than none; perfection is often an enemy of goodness. In fact, if we do not like the distinction between strict products liability and negligence, we should argue for applying strict liability to other cases, not for abandoning it in product cases. There are several responses to this line of argument. First, it is true that my argument has attacked only the distinction between using strict liability in product cases and using negiligence in other cases. I believe strict liability in other cases would be unworkable and pernicious; if a uniform theory is applied to all cases, it should be negligence. Moreover, applying strict liability to other cases is not poitically feasible. But all of this is another matter. It is true that my real objection is the distinction between product cases and other cases. Second, the distinction beiween product cases and otfier personal injury cases is not merely a failure in coherence. As I will demonstrate below, it affirmatively generates pernicious conseguences. The effort to maintain the distinction has itself created serious problems, as we shall see. Sometimes half loaf is not better than none. Third, I agree that law cannot be perfectly rationalized. Sometimes courts (or society) must pick certain areas for reform because reform cannot take place everywhere at once. For example, advocates of universal social accident insurance may not be able to implement such a scheme everywhere, so they might try to begin with one area, such as automobile accidents, workplace accidents, or medical accidents, It is nol clear, however, why pragmatic considerations such as this are applicable to strict products liability as a common law doctrine. Moreover, lack of coherence, in the sense that plausible reasons do not support important doctrinal distinctions, should at least count against a doctrinat scheme, even if it does not ipso facto condemn the scheme. For an interesting discussion of this issue, see Dworkin, supra note 13 , at 177-90. At the very least, careful analysis of the reasons usually given to support strict products liability reveals that they are not as powerful as they seem. In fact, some courts have held that it is as unconstitutional violation of equal protection to distinguish between product cases and other personal injury cases when giving defendants relief through tort reform legislation. See, e.g., Heath v. Sears, Roebuck \& Co., 464 A.2d 288 (N.H. 1983) (special statute of limitations for product cases). While i do not endorse this conclusion as a matter of constitutional mandate, it does refiect the theme of this part: it is difficult to justify a distinction belween product cases and other personal injury cases. (Ironically, the statute of limitations is one area where a distinction does make sense, since product injuries can have such a long lead time.) 


\section{Persistent Problems In Defining Defectiveness}

Strict products liability is not "true" strict liability. The plaintiff must prove more than that the defendant's product injured him. He also must prove that the product was "defective." 48

It is difficult to square the requirement of defect with many of the rationales underlying strict products liability. For example, to the extent that strict products liability rests on a desire to spread accident costs, it is difficult to justify a distinction between accident costs caused by defective products and those caused by nondefective products. As Part II demonstrated, other rationales, such as the proof rationale and consumer expectations, can be squared with the requirement of defectiveness.

After making the original decision to eschew true strict liability in favor of liability based on defectiveness, courts have encountered difficulty defining defectiveness in a way that both is workable and maintains the distinction between strict products liability and negligence. This difficulty has two important consequences for our inquiry. First, the basic concept of defectiveness that has emerged from more than two decades of litigation is so close to negligence that the temaining distinction is not worth the effort to maintain. The similarities between defectiveness and negligence demonstrate that an abandonment of strict products liability would not represent a dramatic shift in the underlying basis of liability. Second, in attempting to maintain the minimal differences that remain, courts have drawn arbitrary, highly complex distinctions that frustrate coherent treatment of similar cases. This part addresses each of these aspects of defectiveness in strict products liability.

\section{Negligence ${ }^{49}$}

A.Defectiveness in Strict Products Liability Is Not Dramatically Different from.

The extent to which strict products liability approximates either true strict liability or negligence depends on the definition of "defect." If courts defined "defect" as "a product that injures the plaintiff," strict products liability would be in fact a version of true strict liability. If, on the other hand, courts defined "defect" as "a product negligently manufactured," strict products liability would be merely a vetsion of negligence parading under another banner. In fact, courts have expended enormous energy trying to define "defect" between these two extremes. The result has been a concept of defectiveness that is far closer to negligence than to strict liability. The small differences that remain between defectiveness and negligence are so strained that they cannot carry the weight of maintaining an entirely separate body of law.

\footnotetext{
${ }^{48}$ Section 402A imposes a requirement that the product be "in a defective condition." Similarly, Greenman v. Yuba Power Prods., Inc., 377 P.2d 897 (Cal. 1963), adopted strict tort hability only for "defective" products.

49 I have examined this issue in another context. See The Persistence of Fault, supra note 5, at 781-97. It is necessary to revisit some of these points because a determination about the wisdom of abandoning strict products liability depends partially on how dramatic such a change would be.
} 
No court ever has defined "defect" to mean "any product condition that causes injury to a plaintiff." Such a definition would entail liability of automobile manufacturers for all automobile accidents, at least if other elements of the cause of action, such as causation or a defense, did not defeat liability. On the other hand, other than in cases involving warnings, no court ever has nominally defined "defect" to be equivalent to negligence. All courts have tried to define "defect" in a supposed middle ground between true strict liability and negligence, but this middle ground has been exceedingly difficult to locate and maintain.

Most courts have relied on one or both of two basic conceptions of defectiveness: (1) the "consumer expectation" test and (2) the "risk-utility" test. ${ }^{50}$ The consumer expectation test reflects the warranty heritage of strict products liability and is embodied in comment i of Restatement (Second) of Torts section 402A. ${ }^{51}$ It provides that a product is defective if the product is more dangerous than an ordinary consumer would contemplate. At first glance, the consumer expectation test seems clearly different from both true strict liability and negligence, and it consequently promises a stable middle ground to serve as a foundation for strict products liability. In fact, this promise is largely illusory.

True, consumer expectations can sometimes provide an independent ground of analysis. Sometimes consumer expectations about product safety are sufficiently concrete that they can serve as a standard for evaluating a product. A manufacturer's advertising or other communications might create concrete expectations that a product can perform safely a specific task..$^{52}$ Even when a manufacturer does not affirmatively create concrete consumer expectations, the offending condition might be sufficiently simple that ordinary consumers have concrete expectations to the contrary - such as when a soft drink contains foreign material. At a more abstract level, consumers might expect at least that a product meets the manufacturer's own specifications, although even here consumers are unlikely to be aware of those specifications or even the range of details they cover..$^{53}$

In most cases, however, consumer expectations do not provide an independent standard against which to judge a product. In most design cases the offending product feature is too complex to generate concrete consumer expectations. Even in simpler cases, consumers are unlikely to have thought much about the specific offending product. Actual consumer expectations about safety are likely to be vague and, more importantly, to oscillate

\footnotetext{
${ }^{50}$ Different courts engraft different details on these basic tests. Some use complicated combinations of them. See, e.g., Barker v. Lull Eng'g Co., 573 P.2d 443 (Cal. 1978). Others use a different test depending on whether the case involves a manufacturing defect, a design defect, or a warning. See, e.g., 3 Committee on Pattern Jury Charges, State Bar of Tex., Texas Pattern Jury Charges, PJC 71.01, $.02, .02 \mathrm{~A}, .04, .05(1982)$. But as a general proposition, courts can ascertain the relationship among defect, true strict liability, and negligence by carefully evaluating the two basic conceptions of defect. ${ }^{51}$ Comment i provides in relevant part; "The article sold must be dangerous to an extent beyond that which would be contemplated by the ordinary consumer who purchases it." Restatement (Second) of Torts $\S 402 \mathrm{~A} \mathrm{cmt.} \mathrm{i} \mathrm{(1964).} \mathrm{For} \mathrm{cases} \mathrm{applying} \mathrm{the} \mathrm{consumer} \mathrm{expectation} \mathrm{test,} \mathrm{see} \mathrm{Gray} v$. Manitowoc Co., 771 F.2d 866 (5th Cir, 1985); Brawner v. Liberty Indus., Inc., 573 S.W.2d 376 (Mo. Ct. App. 1978); Keller v. Welles Dep't Store of Racine, 276 N.W. 2 d 319 (Wis. Ct. App. 1979).

52. The law of express warranties could handle cases in which the manufacturer has affirmatively created a consumer's expectations. See The Persistence of Fault, supra note 5, at 795-97.

${ }^{53}$ Manufacturing defects may be special in this respect.
} 
between "it will never happen to me" and "of course, some products are poorly made." The former expectation proves too much, for it treats every offending product as defective. The latter expectation proves too little, for it treats no product as defective.

Without actual, specific consumer expectations, courts might use the consumer expectation test as a rubric for determining what consumers have a right to expect-for example, that consumers have a right to expect that a product will have cost-effective safety features, will not be negligently manufactured, or at least will meet the manufacturer's own specifications. But this approach still would require courts to determine what consumers have a right to expect. The consumer expectation test itself would not provide the standard. ${ }^{54}$

The consumer expectation test's inability to provide an independent standard of defectiveness for complicated products may explain why its early popularity waned as cases began to involve increasingly complex design features. Some courts have expressly abandoned the consumer expectation test; ${ }^{55}$ others have expressly held that it is synonymous with the risk-utility test. ${ }^{56}$

The consumer expectation test does not provide a powerful reason for eschewing negligence as the underlying standard of liability in product cases. When a manufacturer creates concrete consumer expectations, the law of express warranties or misrepresentation can evaluate those expectations. Some people may he dissatisfied with the substantive law of express warranties and misrepresentation, but that is a different issue; such dissatisfaction provides shaky support for an independent theory of strict products liability that circumvents direct confrontation of the issues.

The second major approach to defectiveness is the risk-utility test. Under it, a product is defective if it has a feature whose risks outweigh its benefits. Because the risk-utility test is very similar to the Learned Hand formula for negligence, ${ }^{57}$ courts have had to expend considerable energy trying to explain how defectiveness under the risk-utility test differs from negligence. The effort has been far from successful..$^{58}$

\footnotetext{
${ }^{54}$ See The Persistence of Fault, supra note 5, at 795-97. This does not mean that a court's decision to instruct the jury to use the consumer expectation test is not important. The language of the instruction may have an important psychological effect on the jury. The issue here, however, is not the psychological effect of various tests of defectiveness, but their normative power.

${ }_{55}$ See generally Tumer v. General Motors Corp. 584 S.W.2d 844 (Tex. 1979). This is certainly not the only explanation. Another motivation has been substantive, that is, that the consumer expectation test deprived plaintiffs of recovery when a "bad" product had a dangerous feature that was nevertheless abvious to ordinary consumers.

${ }^{56}$ See. e.g., Phillips v. Kimwood Mach. Co., 525 P.2d 1033, 1036-37 (Or. 1974).

${ }^{57}$ See United States v. Carroll Towing Co., 159 F.2d 169, 173 (20 Cir. 1947) (defendant negligent if burden (B) of taking precautions would have been less than probability of harm (P) times magnitude of harm $(L)$ : $\mathrm{B}<\mathrm{PL}$ ).

${ }^{58}$ Cost-benefit analyses of accidents pose analytical difficulties, irrespective of whether they occur in the context of negligence or defectiveness. For example, it is extraordinarily difficult to quantify costs and benefits, especially costs and benefits of intangible thems such as pain and suffering. But my purpose here is not to explicate fully the way in which courts can or should apply a cost-benefit analysis to personal injury cases. Instead, it is to determine whether the supposed difierences between a cost-benefit analysis of defectiveness and a cost-benefit analysis of negligence are sufficiently strong to justify maintaining separate theories of liability. For further discussion of the cost-benefit analysis generally, see The Persistence of Fault, supra note 5 , at 784-87.
} 
Some courts that use the risk-utility test of defectiveness claim that it is different from negligence because it focuses on the product, not on the manufacturer's conduct. ${ }^{59}$ Thus, negligence asks whether a manufacturer adopted manufacturing procedures with a reasonable balance between risk and utility, whereas defectiveness asks whether the product as it was made actually has risks that outweigh its benefits. In fact, however, this distinction is difficult to maintain. The supposed distinction between negligence and defectiveness under the riskutility test depends on the role foreseeability plays in each theory. In negligence, only reasonably foreseeable risks count against a defendant; whereas in defectiveness, all actual risks known at the time of trial count against the manufacturer, whether the manufacturer reasonably could have foreseen them at the time of sale. Thus, we are told, negligence employs a foresight test, whereas defectiveness employs a hindsight test.

Under the foresight test of negligence, a manufacturer is responsible only for risks that were reasonably foresceable when the product was sold. In the context of product cases, reasonable foreseeability turns on whether the manufacturer used reasonable care in finding out about product risks, that is, whether the manufacturer engaged in reasonable research, development, and testing. A manufacturer can argue that the burden of engaging in more extensive testing was not cost-justified. Under the hindsight test of defectiveness, however, a manufacturer cannot count in its favor the burden of finding out about a risk. A manufacturer still can argue that the risk was worth imposing, because the product has offsetting advantages, but the manufacturer cannot count in its favor the burden of finding out about the risk.

A second approach distinguishing between negligence and defectiveness (defined in risk-utility terms) is sometimes plausible in cases involving manufacturing defects. In negligence cases - in which the jury is asked to evaluate the manufacturer's conductthe manufacturer can argue that the additional (marginal) cost of quality control procedures necessary to eliminate the flaw outweighed the risk of having a few flawed products. For example, a soft drink bottler can argue that existing quality control procedures, such as fitters and random inspection, are adequate to eliminate impurities in all but a very few cases. To reduce the risk even further might not be worth the additional expense of more sophisticated quality control measures. Under the risk-utility standard of defectiveness -w-which purports to evaluate the product instead of the manufacturer's conduct - the manufacturer could not use this argument. The relevant inquiry would be whether the product feature - here the impurity -itself had utility that outweighed its risks. Because the value of a flaw is usually zero, flaws that increase a product's risks (nearly) always are defective under this analysis.

In the contexts of both foreseeability and quality control, the difference between negligence and the risk-utility test of defectiveness is that in negligence, the manufacturer can rely on certain burdens to justify a product's risks- the burdens of research,

59 See Caterpillar Tractor Co. v. Beck, 593 P.2d 871, 889 (Alaska 1979); Phipps v. General Motors Corp., 363 A.2d 955, 958-59 (Md. 1976); Phillips, 525 P.2d at 1036; see also Page Keeton, Products Liability-Liability Without Fault and the Requirement of a Defect, 41 Tex. L. Rev. 855 (1963); W. Page Keeton, The Meaning of Defect in Products Liability -A Review of Basic Principles , 45 Mo. L. Rev. 579, 592 (1980). 
development, testing and quality control respectively - that it cannot rely on under the riskutility test of defectiveness. By removing these arguments of justification from the defendant, the risk-utility test of defectiveness is more favorable to the plaintiff than is negligence. Consequently, the two theories of liability are distinct.

A question remains whether it makes sense to predicate a distinction between strict products liability and negligence on the different treatment each theory gives to burdens involved in foreseeing risks and implementing quality control measures. One consideration is whether these distinctions actually make much of a difference in many cases. In fact, the distinction between a foresight test and a hindsight test, by definition, makes a difference only in cases in which a product's risks were unforeseeable. In some cases, for example drug cases, product risks are commonly unforeseeable when the product is sold. Outside the area of drugs, the risk of toxic shock syndrome from superabsorbent tampons may be the most celebrated case of a truly unforesecable risk. But in many cases the consumer knows of a product's offending risks at the time of purchase. In these cases no difference exists between negligence and defectiveness under the risk-utility test. And in cases involving warnings, most courts openly use a foresight (negligence) test. ${ }^{60}$ This does not mean that the difference between a foresight test and a hindsight test is never important, but the fact that the distinction is itrelevant in many cases is significant for deciding whether to maintain the distinction between negligence and strict products liability.

A second consideration is whether distinguishing between a product and the manufacturer's conduct makes sense. In fact, the distinction between evaluating a product and evaluating the manufacturer's conduct (and the concomitant distinctions between the respective treaments negligence and defectiveness give to the burdens of discovering a product's risks and of implementing qualiry control measures) does not withstand closer scrutiny, ${ }^{61}$

${ }^{60}$ See. e.g., Borel v. Fibreboard Paper Prods. Corp., 493 F.2d 1076, 1089.90 (1973), cert. denied, 419 U.S. 869 (1974); Feldman v. Lederle Lab., 479 A.2d 374 (N.J. 1984). But see Beshada v. Johns-Manville Prods. Corp., 447 A.2d 539 (N.J. 1982); Little v. PPG indus., 579 P.2d 940, 946 (Wash. Ct. App. 1978). See generally Restatement (Second) of Torts $\$ 402 \mathrm{~A} \mathrm{cmt.j} \mathrm{(1964).}$

6i Some courts have encountered linguistic confusion when they have tried to distinguish between negligence and defectiveness under the risk-utility test. Sometimes this linguistic confusion occurs when courts try to develop jury instructions, but sometimes even the courts themselves have become confused. See. e.g., Newman v. Utility Trailer \& Equip. Co., 564 P.2d 674 (Or. 1977) (holding that reasonable seller must weigh foreseeable risk of harm); Johnson v. Clark Equip. Co., 547 P.2d 132 (Or. 1976) (arguing that assumption of risk in strict liability is a negligence hybrid); Phillips, 525 P.2d 1033 (cornmenting on confusion experienced by other courts). One source of this confusion has been a heuristic device by which courts have explained the risk-utility test of defectiveness. These courts have defined defectiveness by referring to the conduct of a reasonably prudent manufacturer who is actually aware of the risk the product imposes. See id. at 1036; Page Keeton, Manufacturer's Liability: The Meaning of "Defect" in the Manufacture and Design of Products, 20 Syracuse L. Rev. 559, 568 (1969); John W. Wade, Strict Tort Liability of Manufacturers, $19 \mathrm{Sw}$. L.J. 5, 15-16 (1965). This formulation of the risk-utility test is analytically different from negligence because it assumes foreseeability and ignores the burden of discovering product risks. It is not surprising, however, that some courts have seized upon the reference to a "reasonably prudent manufacturer" as a reference to negligence.Linguistic confusion has been an important practical problem, but it does not itself undermine the analytical distinction between defectiveness and negligence. Careful jury instructions can mitigate jury confusion, and careful analysis can avoid judicial confusion. But the problem of maintaining a distinction between negligence and defectiveness under the risk-utility test reflects a problem that is more fundamental than mere linguistic confusion. 
Every product imposes risks, and nearly every product could be made safer. Most products are not defective, however, because they impose risks that are socially worthwhile. For example, automobiles impose risks, but they provide a valuable means of transportation. This type of balancing is the essence of the risk-utility test of defectiveness.

Some risks are acceptable because they are concomitants of socially desirable product features. The speed of automobiles and the sharpness of knives provide concomitant risks and benefits. Other risks are acceptable because products that avoided them would be inordinately expensive. Consequently, product cost is an appropriate factor in a risk-utility balance. ${ }^{62}$ In fact, if courts ignored product cost, nearly every product that imposes risks would be defective, because nearly every product could be made safer at some cost.

Product cost, however, is merely a reflection of the product's manufacturing process; a court that considers product cost ipso facto evaluates the manufacturer's conduct. Consequently, including product cost in a determination of defectiveness intrinsically undermines the distinction between evaluating the product and evaluating the manufacturer's conduct. This, in tum, undermines the supposed distinction between defectiveness and negligence.

Consider a compact automobile that imposes a greater risk of injury during a crash than does a larger sedan. Under the risk-utility test of defectiveness, a manufacturer could argue that benefits such as fuel economy and ease of handling outweigh the risks of small cars. The manufacturer also could argue that small cars are less expensive to build because they require less labor and materials. Because even the cost of materials reflects the labor necessary to produce them, a risk-utility justification for compact cars based on cost is largely based on labor savings. The risk utility test provides no justification for excluding these labor costs from its ambit.

The problem is that a product's cost also reflects foreseeability. Almost any risk is foreseeable if a product is tested sufficiently. In negligence the issue is whether a risk is reasonably foreseeable, an issue that depends on the reasonableness of the manufacturer's decision to forego further testing. If a reasonably prudent manufacturer would believe that additional research would not be cost-effective, a decision to forego the research would be reasonable, and the risks it would have disclosed would not have been reasonably foreseeable. Risks that are not reasonably foreseeable do not count against a manufacturer in a cost-benefit analysis to determine negligence.

But the analysis is identical under defectiveness when product cost is taken into account. The cost of the product reflects the burden of testing in the same way that the cost of the product reflects the cost of labor and material. A manufacturer's decision to forego further testing would make a compact car cheaper, just as would a decision to save other labor and material costs. Because product cost is a factor in the risk-utility test for determining defectiveness, courts could consider the burden of testing precisely to the same extent in strict liability as in negligence. This is just an example of a general problem. Because product cost

62 See. e.g., Caterpllar, 593 P.2d at 886; Turner v. General Motors Corp., 584 S.W.2d 844, 846 (Tex. 1979); W. Page Keeton, Product Liability and the Meaning of Defect, 5 St. Mary's L.J. 30, 38 (1973). 
simply reflects the burdens of the manufacturing process, the entire distinction between evaluating a product and evaluating a manufacturer's conduct is illusory.

An analogous problem arises when we apply the risk-utility test to manufacturing defects. Manufacturing defects appear to present easy cases under the risk-utility test, because the utility of a flaw appears to be zero. In a negligence case a manufacturer could try to justify its fallure to prevent or discover a flaw by relying on the burden of improved quality control procedures. In an analysis of a product's defectiveness, however, the reasonableness of foregoing quality control improvements nomally is not relevant. But a product's cost reflects the decision to forego additional quality control expenses, so a hidden benefit of a law is cheaper product cost. Because product cost is supposedly relevant to determine defectiveness, defectiveness seems to account for the burden of quality control to the same extent as does negligence. ${ }^{63}$

The distinction between defectiveness and negligence can be maintained by arbitrarily excluding research and development costs and quality control costs from the risk-utility test of defectiveness. In fact, courts implicitly have done so to preserve the distinction between negligence and defectiveness in cases involving manufacturing defects and design defects. However, courts have not articulated reasons for permitting manufacturers to justify risks with reference to certain components of product cost but not with reference to others. The values that motivate courts to permit manufacturers to justify risks with reference to labor and material costs seem to be just as applicable to research and development costs and quality control costs. But without this arbitrary distinction, product cost is merely a reflection of the burdens of the manufacturing process, and the distinction between defectiveness and negligence disappears.

It is important to reiterate that this does not mean that courts cannot or have not maintained a distinction between negligence and defectiveness. They can do so and have done so by ignoring the burdens of research and development and of quality control. Nor does this mean that it would not be possible to develop rationales for ignoring these burdens but not others. Maybe the burdens of research and development or quality control are more difficult to prove or more difficult fot a jury to evaluate. Nor does this mean that different fury instructions do not have a psychological impact on a jury's deliberations.

Courts, however, have not expressly decided to differentiate between strict products liability and negligence by allowing manufacturer to justify product risks with reference to certain components of product cost but not others. Moreover, no powerful reasons exist for making such a distinction. Understanding the strength of current resistance against abandoning strict products liability on the basis of these fine distinctions among various components of product cost is difficult. But it is only these fine distinctions that separate the underlying standard of negligence from strict products liability under the risk-utility test. In this sense, abandoning strict products liability would be only a modest change.

\footnotetext{
${ }^{63}$ Because the distinction between negligence and defectiveness in warnings cases turns almost entirely on the issue of foreseeability, the analysis in warnings cases is similar to the analysis in design cases.
} 


\section{B.Courts Have Drawn Indefensible Distinctions To Define Defectiveness}

In subpart A, I argued that the distinctions courts have used to separate negligence and defectiveness are so slender that abandoning them would not be a dramatic change. In this subpart I argue that these and other distinctions courts draw when defining defectiveness are arbitrary.

One of the supposed rationales underlying strict products liability is that it incorporates injury costs into the price of the product, spreads them among the entire range of consumer, and thereby removes the cost of injury from the shoulders of an individual victim. ${ }^{64}$ All consumers of the product pay the higher price, so it is important under this theory that the law makes decisions about distributing the money to infured victims according to standards that reflect at least plausible distinctions among cases. ${ }^{65}$

In defining defectiveness, courts have drawn distinctions among groups of cases that are arbitrary and do not represent reasonable compromises between compering arguments for strict liability and negligence. One device courts have used is to distinguish among different types of defects. Courts have developed different standards of defectiveness for cases involving manufacturing defects, design defects, and warnings defects; some courts have used three different standards in these three different situations. ${ }^{66}$ Section $402 \mathrm{~A}$ itself does not invite courts to use different standards of defectiveness depending on the type of defect. Nevertheless, courts commonly have done so, oscillating between the tugs of strict liability and negligence by using one approach in one type of case and another approach in another type of case.

This practice raises a question whether distinctions among the three types of defects are plausible, given the supposed policy rationales of strict products liability. ${ }^{67} \mathrm{~A}$

\footnotetext{
${ }^{64}$ See, e.g., Helene Curtis Indus., Inc. v. Pruitt, 385 F.2d 841, 862 (5th Cir. 1967), cert denied, 391 U.S. 913 (1963); Escola v. Coca Cola Bottling Co. of Fresno, 150 P.2d 436, 441 (Cal, 1944) (Traynor, J., concurring); Tumer, 584 S.W.2d at 853-54 (Campbell, J, concurting); Davis v. Gibson Prods. Co., 505 S.W.2d 682, 690 (Tex. Civ. App. 1973), writ refused, 513 S.W.2d 4 (Tex. 1974); Hoven v. Keible, 256 N.W.2d 379, 391 (Wis. 1977); Epstein, supra note 17, at 19-20.

${ }_{65}^{6}$ Any system is fair ex ante, as long as the participants do not know in advance whether they will be on one side or the other of a doctrinal distinction that triggers recovery. Ex ante, a rule that permitted recovery for people who were injured on Tuesday but not Wednesday would be fair. Nevertheless, most people would believe that such a rule is arbitrary, because it does not reflect justifiable distinctions that we would consider to be fair ex post.

${ }^{66}$ Most courts at least use a different standard in wamings cases than in other types of cases. See, e.g., Green v. American Tobacco Co., 409 F.2d 1166 (5th Cir. 1969) (applying Florida law); Ross v. Philip Morris \& Co., 328 F.2d 3 (8th Cir. 1964) (applying Missouri Law); Lartigue v. R.J. Reynolds Tobacco Co., 317 F.2d 19 (5th Cir.), cert. denied, 375 U.S. 865 (1963) (applying Loulsiana law); Feldman v. Lederle Lab., 479 A.2d 374 (N.J. 1984). See generally Restatement (Second) Of Torts $\$ 402 \mathrm{~A} \mathrm{cmt.j}$ and reporter's notes, at 353 (1964), Some states also distinguish between manufacturing defects and design defects. See, e.g., 3 Commitee on Pattern Jury Charges, supra note 50, PJC 71,01, 03 (manufacturing defects governed by consumer expectation test, designer defects governed by hindsight version of risk-utility test, and warnings defects governed by amalgam of foresight and consumer expectations).

67 The fact that most of the articulated policy rationales of strict liability do not even support a distinction between product cases and nonproduct cases, or between defective products and non-defective products complicates an answer to this question. Nevertheless, the articulated underpinnings of strict products liability are at least a starting point to determine whether any meaningful distinctions exist among cases involving manufacturing defects, design defects, and warnings. See supra notes 6-47 and accompanying text.
} 
plausible distinction does exist between cases involving manufacturing defects on the one hand and design defects or warnings on the other hand. The proof problem is especially acute in cases involving manufacturing defects, because a plaintiff faces special difficulties proving specific acts of negligence that caused a flaw. ${ }^{68}$ Consequently, a difference in the underlying standard of liability that reflects this problem may be appropriate in cases involving manufacturing defects, even though it would not be appropriate in cases involving design defects or warnings.

Moreover, cases involving manufacturing defects may be more amenable to resolution under the consumer expectation test, because they often involve product conditions that frustrate concrete consumer expectations. The difficulties inherent in the consumer expectation test that I discussed in subpart $\mathrm{A}$-ascertaining actual consumer expectation for complicated products-may not be as acute in cases involving flaws. Consequently, using the consumer expectation test in cases involving flaws but not in cases involving design defects or warnings is plausible. ${ }^{69}$

\footnotetext{
${ }^{68}$ See supra notes 6-47 and accompanying text.

${ }^{69}$ Even in cases involving flaws, the consumer expectation test raises some difficulties. When an impurity or product condition exceeds a manufacturer's own specifications, we might say that the product violates consumer expectations, because consumers expect, or have a right to expect, that a product meets the manufacturer's own specifications. Even here, however, we are in danger of using consumer expectations as a rubric for what we think consumers have a right to expect, not as a conclusion about what they actually expect. Nevertheless, the consumer expectation test does not seem jarringly out of place in these cases. In some cases, however, the manufacturer might not have a specification addressing the impunity. Even if flawed products are defective per se, courts must still determine when an abnormality is sufficiently substantial to constitute a flaw. All products vary from the norm in minute detail. For example, steel has slight imperfections when viewed microscopically. See Alvin S. Weinstein \& Aaron D. Twerski, Product Llability: An interaction of Law and Technology, 12 Duq. L. Rev. 425, 430 (1974). The plaintiff's interests are better served when the court examines the product with an attention to detal that brings imperfections into prominence. See Signal Oil \& Gas Co. v. Universal Oil Prods., 572 S.W.2d 320 (Tex. 1978); Fitzgerald Marine Sales v. Le Unes, 659 S.W.2d 917 (Tex. Ct. App. 1983, writ dismissed 1984); Ethicon Inc. v. Parten, 520 S.W.2d 527, 531 (Tex. Civ. App. 1975). The defendant has an advantage if the court views the product from a larger perspective. See Bames v. General Motors Corp., 653 S.W.2d 85 (Tex. Ct. App. 1983, writ refused). A few stress fractures in a carload of steel beams seem insignificant, but a single stress fracture in a single part in as airplane seems very significant. In some cases, a court might rely on industry or governmental standards to determine whether an imperfection constitutes a flaw, although conformance to industry or government standards does not conclusively demonstrate that a product is not defective. See Ellis v. K-Lan Co., 695 F.2d 157, 161, 162 n.5 (5th Cir, 1983); Simien v. S.S. Kresge Co., 566 F.2d 551, 554, 557 (5th Cir. 1978). A court could also apply either the consumer expectation test or the risk-utility test to determine whether a specific degree of imperfection constitutes a flaw, but doing so would raise all of the problems with these two tests that were addressed supra part ll..A. For a general discussion of this issue, see Powers, supra note $16 . \S 5.032$.
} 
A distinction between design cases and warnings cases, however; does not make sense. Most courts use a hindsight test to evaluate design defects, whereas they use a foresight test to evaluate warnings, ${ }^{70}$ but none of the rationales courts have articulated to support strict products liability justify this different treatment. The proof rationale does not justify a hindsight test for design defects but a foresight test for warnings, because proving that a manufacturer's research and development efforts were unreasonable is no more difficult in a design case than in a warnings case. At least no court has ever claimed that design cases differ from warnings cases in this regard.

The spreading rationale does not justify this distinction because spreading accident costs over the entire body of consumers is just as attractive in cases involving wamings as it is in cases involving the physical characteristics of a product's design. Why should it matter whether a dangerous product feature is physical or informational? A product that is unreasonably dangerous is no less so merely because an informational feature, rather than a physical design feature, created the risk. Again, no court has offered a rationale for this distinction. ${ }^{71}$ In fact, a few courts have rejected the distinction by applying a hindsight test to warnings.

See Parke-Davis \& Co. v. Stromsodt, 411 F.2d 1390 (8th Cir. 1969) (applying Notth Dakotalaw); Tinnerholm v. Parke-Davis \& Co., 411 F2d 48 (2nd Cir. 1969) (applying New York law); Gogol v. Johns-Manville Sales Corp., 595 F. Supp. 971 (D.N.J. 1984); Flatt v. Johns-Manville Sales Corp., 488 F. Supp. 836,841-42 (E.D. Tex. 1980) (interpreting Borel v. Fibreboard Paper Prods. Cotp., 493 F.2d 1076 (5thCir. 1973), cert. denied, 419 U.S. 869 (1974)); Beshada v. JohnsManville Products Corp, 447 A.2d 539 (N.J. 1982) (but see Feldman v. Lederle Lab., 472 A.2d 374 (N.J. 1984)); Schering Corp. v. Giesecke, 589 S.W.2d 516 (Tex. Civ. App. 1979, writ refused 1980); Hamilton v. Motor Coach Indus., Inc., 569 S.W.2d 571, 577 (Tex. Civ. App. 1978); Little v. PPG Indus., Inc., 594 P.2d 911 (Wash. 1979); see also Leon Green, Strict Liability Under Sections 402A and 402B: A Decade of Litigation, 54 Tex. L. Rev. 1185, 1203-06, 1211-12, 1219

\footnotetext{
${ }^{70}$ Most courts at least use a different standard in warnings cases than they use in other types of cases. See supra note 66. The different treatment of warnings cases may have another source. Some warnings actually make a product safer; others do not. A warning that informs consumers about risks that occur only in certain recognizable situations, such as a drug's risks to fetuses, makes a product safer, because consumers can avold using the product in the dangerous circumstances. Instructions about using a product- - such as an instruction that paint should not be used near a flame - can also make the product safer. See Jackson v. Coast Paint \& Lacquer Co., 499 F.2d 809 (9th Cir. 1974). Other types of warnings, however, do not make a product safer. For example, a warning that a drug has a rare side effect does not make the diug safer if we cannot identify in advance the situations in which the side effect will occur. See Reyes v. Wyeth Lab., 498 F.2d 1264 (5th Cir.), cert. denied, 419 U.S. 1096 (1974). The justification for such a warning is consumer autonomy, not product safety. Even if such a warning does not make a product safer, it permits consumers to decide for themselves whether to incur the risk. Thus, we might distinguish between "safety warnings" and "autonomy warnings."Autonomy warnings are not about product safety at all. They do not affect the risk test of defectiveness, because they do not decrease a product's risk. Thus, it would be plausible to exclude autonomy warnings from strict products liability. Courts may have responded to this concern in a nondiscriminating way by eschewing hindsight in all warnings cases. But the fact remains that it is still difficult to justify applying a foresight test to safety warnings when a hinosight test governs design defects. This is not to say that powerful arguments cannot be made favoring a foresight test in cases involving safety warnings. The point is that the arguments are no more powerful for safety warnings than for design defects.
} 
(1976); W. Page Keeton, Products Liability -Inadequacy of Information, 48 Tex. L. Rev. 398 (1970); John A. Kidwell, Duty to Wann: A Description of the Model of Decision, 53 Tex. L. Rev. 1375, 1383-90 (1975); Charles C. Marvel, Annotation, Strict Products Liability: Liability for Failure to Warn as Dependant on Defendant's Knowledge of Danger, 33 A.L.R.4th 368 (1984).

Even within the category of design defects, courts have drawn arbitrary distinctions to define defectiveness. As we saw in subpart $A$, the distinction between defectiveness under the risk-utility test and negligence depends upon keeping research and development costs out of the risk-utility analysis. One litigant cannot recover because a design change would unreasonably increase the product's cost to the manufacturer and, therefore, to consumers. Another litigant, however, can recover without regard to product cost, simply because the source of the added cost would have been extra research and development. Courts have not explained satisfactorily why the first litigant can recover while the second cannot. The source of the additional component of product cost does not seem to be a promising explanation.

"The "state-of-the-att" defense exacerbates the problem of arbitrariness within the category of design defects. Not all states have adopted the state-of-the-art defense, and those that have do not always agree about its precise contours. But, in its basic form, it enables a manufacturer to argue that its product should be judged only against alternative designs that were technologically feasible at the time the product was sold. An airplane built in 1940 would not be defective for failing to incorporate radar, because radar was not technologically feasible in $1940{ }^{72}$

${ }^{72}$ See Reed v. Tiffin Motor Homes, inc., 697 F.2d 1192 (4th Cir. 1982) (applying South Carolina law); Bruce v. Martin-Marietta Corp., 544 F.2d 442 (10th Cir. 1976) (applying Maryland and Missouri law); Spurlin v. General Motors Corp., 528 F.2d 612 (5th Cir. 1976) (applying Alabama law); Ward v. Hobart Míg. Co., 450 F.2d 1176 (5th Cir. 1971) (applying Mississippi law); Caterpillar Tractor Co. v. Beck, 593 P.2d 871 (Alaska 1979); Barker v. Lull Eng'g Co. 573 P.2d 443 (Cal. 1978); Kerns v. Engetke, 76 III. 2d 154, 390 N.E.2d 859, 28 III. Dec. 500 (1979); O'Brien v. Muskin Corp., 463 A.2d 298 (N.J. 1983); Boatland of Houston, inc. v. Balley, 609 S.W.2d 743 (Tex. 1980). The state-of-the-art defense does not absolutely insulate a product from a finding of defectiveness. Even if an alternate design was not feasible, a product might stilt be defective for being put on the market at all. The state-of-the-art defense merely holds that an alternate design cannot be used to render a product defective if the alternate design was not technologically feasible when the product was sold. State of the art is supposedly different from industry custom. An industry failure to adopt a technologically feasibie alternative is opinion evidence about the desirability of the alternative, but the industry may have been wrong, and the jury will be permitted to decide otherwise. See 566 F.2d 551; Turner v. General Motors Corp., 584 S.W.2d 844, 852.53 (Tex. 1979). State of the art is supposedly different from mere economic feasibility. The line between technological infeasibility and infeasibility is very difficult to maintain, however. Technological feasibilify depends on research and development. Radar would have been avallable in 1940 if sufficient resources had been devoted to its development in the preceding decade. Moreover, even without the state-of-the-art defense, product cost is relevant under the risk-utility test, and product cost implicates economic feasibility.Courts are often unclear about the precise impact of the state-of-the-art deferise. If state of the art rests on a judgment that a manufacturer cannot fairly be held responsible for a design feature that was not technologically available when the product was sold, a manufacturer who conciusively proves that the plaintiff's only proposed alternative design was not technologically feasible should be entitied to a directed verdict. Most courts, however, have stated that technological feasibility is just a factor that the jury can consider.Maybe this is because the technological feasibility of the design is itself in dispute, which would defeat the defendant's motion for a directed verdict. But in some cases this will not be an issue, and, in any event, the issue is forced by deciding the appropriate jury instruction in cases where technological feasibility is itseif in dispute. In most jurisdictions, courts seem to treat state of the art as only a factor, not an absolute bar to liability. See generally Boatland of Houston, 609 S.W.2d 743. 
State of the art rests on a powerful argument that holding a manufacturer responsible for a design feature that would have been impossible to change when the product was sold is unfair. But this argument is an argument about fault, which is antithetical to the supposed "strict" nature of strict products liability. Thus, state of the art is difficult to square with the hindsight test of defectiveness in design cases, which rejects arguments about fault. Nor do any of the policies courts invoke to justify strict products liability explain the competing tugs of the state-of-the-art defense and the hindsight approach. For example, whether a product risk for which there was a feasible technological alternative at the time the product was sold caused an injury makes little difference to the spreading rationale. ${ }^{33}$

Taken in isolation, two tationales do seem to support the state-of-the-art defense. Courts often claim that the fact that the manufacturer is in a better position than the consumer to protect against a risk justifies strict products liability. ${ }^{74}$ This is a close cousin to the argument that strict products liability will justify product safety by encouraging manufacturers to make products safe. ${ }^{75}$ If we can agree that no technologically feasible alternative was available when the product was sold, the manufacturer was hardly in a position to eliminate the risk.

A similar argument can be couched in terms of the proof rationale. ${ }^{76}$ Negligence, not just strict products liability, encourages manufacturers to make reasonably safe products. Only when a cost-benefit balance does not call for additional safety does negligence let the manufacturer off the hook. The problem is that we sometimes cannot identify when a manufacturer was negligent. Thus, we infer negligence from the existence of a defect, which is easier to prove. When a manufacturer makes a product that meets the state of the art, we cannot infer negligence.

The problem with these arguments, however, is that they are equally applicable to the technological infeasibility of finding out about a risk. But if we permitted a defendant to escape liability on the ground that the risk was impossible to discover under technology available at the time the product was sold, we would completely reject the hindsight perspective of defectiveness. This, in tum, would be tantamount to abandoning the supposed difference between defectiveness and negligence.

The distinction between a manufacturer's inability to discover a risk and its inability to change the design to avoid a risk is arbitrary. True, courts can draw a doctrinal distinction

${ }^{73}$ Of course, no test of defect fits the spreading rationale.

${ }^{74}$ See Greenman v. Yuba Power Prods., Inc., 377 P.2d 897 (Cal. 1963); see also Heaton v. Ford Motor Co., 435 P.2d 806 (Or. 1967); McCown v. International Harvester Co., 342 A.2d 381 (Pa. 1975); Salvador v. Atlantic Steel Boller Co., 319 A.2d 903 (Pa. 1974); Henderson V. Ford Motor Co., 519 S.W.2d 87 (Tex. 1974); Vincer v. Esther Willams Ali-Aluminum Swimming Pool Co., 230 N.W.2d 794 (Wis. 1975).

${ }^{75}$ See, e.g., Turner, 584 S.W.2d 844 (Campbell, J., concurring); Hoven v. Kelble, 256 N.W.2d 379 (Wis. 1977): Epstein, supra note 17, at 19-20; Riper, supra note 17, at 393.

${ }^{76}$ See, e.g., La Rossa v. Scientific Design Co., 402 F.2d 937, 942 (3d Cir. 1968); Escola v. Coca Cola Boltting Co. of Fresno, 150 P.2d 436, 441 (Cal. 1944) (Traynor, J., concurring); Phipps v. General Motors Corp., 363 A.2d 955, 958 (Md. 1976); Pitsburg Coca-Cola Bottling Works v. Ponder, 443 S.W.2d 546, 548-49 (Tex. 1969); Jacobs v. Technical Chem. Co., 472 S.W.2d 191, 197-98 (Tex. Civ. App, 1971), rev'd on other grounds, 480 5.W.2d 602 (Tex. 1972); Hoven, 256 N.W.2d at 391; Cowan, supra note 34, at 1087; Keeton, supra note 37, at 26-39; Montgomery \& Owen, supra note 37, at 809; Riper, supra note 17 , at 395 . 
to sort out the cases, but what are we to tell the litigants about why the law has drawn such a distinction? Consider two plaintiffs. One is permitted to recover, even though the defendant had no technically feasible way to discover the offending risk. The defendant was not blameworthy, because we could not reasonably have expected it to do better, but strict products liability does not require a finding of fault. Consequently, the plaintiff wins. The other plaintiff however, is not permitted to recover, because the defendent had no technologically feasible method of reducing the risk. As in the first case, the defendant reasonably could not have prevented the injury, but contrary to our conclusion in the first case, we defer to the defendant's argument here, acquiescing in its claim of blamelessness.

Courts have offered no justification for this distinction. Instead, they appear to have swung uncertainly between the arguments for strict liability and the arguments for fault-based liability. On the manufacturer's ability to discover a risk they have deferred to strict liability; on the manufacturer's ability to reduce a risk they have deferred to fault. The result is not an alloy of the two theories: it is a patchwork mixture with arbitrary boundaries.

All consumers pay for liability through higher prices. They should benefit from the resulting compensation scheme equally or according to fair distinctions. Compensation to some claimants but not to others, based on arbitrary distinctions, is unfair. Using different tests of defectiveness depending on the type of defect, maintaining the hindsight perspective of defectiveness by distinguishing among different kinds of product costs, and applying state of the art to a manufacturer's inability to change a product's design but not at manufacturer's inability to discover a risk are three arbitrary distinctions that undermine the fairness of strict products liability as a compensation scheme. An open shift to negligence would eliminate the need for these distinctions.

\section{IV. "Collateral" Doctrines}

On several recurrent general problems of personal injury litigation, courts deciding products liability cases have felt free to depart from solutions developed in the context of negligence. Often, there is no good reason for distinguishing between negligence and strict products liability on these issues, but the existence of strict products liability as a "separate" cause of action provides courts and attorneys with a facile distinction to rationalize a different solution for product cases. Thus, the insistence that strict products liability is a separate cause of action invites courts to write on a clean slate with respect to these issues. An attorney on one side of the case almost always will be motivated to reinforce this invitation.

Nothing in the logic of strict products liability requires courts to resolve these collateral issues differently under strict products liability than under negligence, but the psychology of calling strict products liability a different cause of action can cause courts to think they are writing on a clean slate and grapple again with issues that otherwise had been resolved-and it can arbitrarily create disparate treatment of issues depending on whether a case involved a product. 


\section{A.Delegability}

Several courts have grappled with the question of whether a manufacturer can delegate the duty to design a reasonably safe product or to give an appropriate warning..$^{77}$ With some exceptions, manufacturers have a duty under negligence law to use reasonable care under the circumstances. ${ }^{78}$ If a manufacturer relies on an intermediary to incorporate a safety device or pass along a warning, negligence law asks whether a reasonable manufacturer under the circumstances would have relied on the intermediary to provide for safety. For example, a manufacturer might rely on an assembler of component parts to add safety devices or to make sure that the component parts are properly assembled. ${ }^{79}$ It might rely on a purchaser of industrial equipment to install safety devices necessary to use the equipment safely in conjunction with other equipment. ${ }^{.02}$ It might rely on a purchaser of equipment with multiple uses to select safety options that are suitable to the purchaser's particular use. ${ }^{81}$ Or, a manufacturer of a bulk product or of a drug might rely on an intermediary who packages the bulk product or prescribes the drug to pass along a warning ${ }^{82}$ In each case, a court normally would ask whether the manufacturer's reliance on the intermediary was "reasonable." Specifically, it would ask about the foreseeability of the risk, the difficulty of the manufacturer making the safety improvement itself, the danger to the ultimate user, and the reliability of the intermediary. Thus, in a warnings case a court might approve of manufacturer of a bulk product relying on an intermediary who puts the product into packages, if it is difficult for the manufacturer to communicate a warning to consumers and if the intermediary is itself a reliable expert. The decisive issue, usually for the jury to decide, would be whether the manufacturer acted reasonably under the circumstances. ${ }^{83}$

\footnotetext{
${ }^{77}$ See, e.g., Verge v. Ford Motor Co., 581 F.2d 384 (3d Cir. 1978); Goodbar v. Whitehead Bros., 591 F. Supp. 552 (W.D. Va. 1984); Union Supply Co. v. Pust, 583 P.2d 276 (Colo. 1978); Rios v. Niagra Mach. \& Tool Works, 12 III. App. 3d 739, 299 N.E.2d 86 (1st Dist. 1973), aff'd, 59 Ill 2d 79, 319 N.E.2d 232 (1974); Bilotta v. Kelley Co., 346 N.W.2d 616 (Minn. 1984); State Stove Mfg. Co. v. Hodges, 189 So. $2 d 113$ (Miss. 1966), cert, denied sub nom. Yates v. Hodges, 386 U.S. 912 (1967); Bexiga v. Havir Mfg. Corp., 290 A.2d 281 (N.J. 1972); Bacardi v. Holzman, 442 A.2d 617 (N.J. Super. Ct. App. Div. 1981); Mott v. Callahan AMS Mach. Co., 416 A.2d 57 (N.J. Super. Ct. App. Div. 1980).

${ }^{76}$ A few courts apply some special "no duty" rules to manufacturers, such as no duty to design or wam against "open and obviols" dangers. See, e.g., Ganes v. Gulf \& W. Mfg. Co., 789 F.2d 637 (8th Cir. 1986); Campo v. Scofield, 95 N.E.2d 802 (N.Y. 1950). But see Micallef v. Miehte Co., 348 N.E.2d 571 (N.Y. 1976). The most famous historical no duty rule for manufacturers was that a manufacturer's duty normally extended only to persons who were in privity of contract with the manufacturer. Of course, courts have abandoned this rule. See MacPherson v. Buick Motor Co., 111 N.E. 1050 (N.Y. 1916).

${ }^{79}$ See Union Supply Co. v. Pust, 583 P.2d 276 (Colo. 1978).

30 See Mott v. Callahan AMS Mach. Co., 416 A.2d 57 (N.J. Super. Ct. App. Div. 1980).

81 See Verge, 581 F.2d at 389 ; Bilotta, 346 N.W.2d at 624.

${ }^{82}$ See Goodbar v. Whitehead Bros., 591 F. Supp. 552 (W.D. Va. 1984); Bacardi v. Holzman, 442 A.2d 617 (N.J. Super. Ct. App. Div. 1981).

${ }^{23}$ In cases involving a decision to add safely equipment to a product, a court would ask how feasible it would have been for the original manufaciurer to have incorporated the safety device into the product. If the product is a multipurpose machine, it would have been difficult for the manufacturer to have incorporated a safety device that would be compalible with each use. Again, the decisive issue is whether the manufacturer acted reasonably under the circumstances by relying on someone else to incorporate the safety device.
} 
Several courts have used a functionally identical analysis under strict products liability. They have held that a manufacturer of a bulk product can rely on a subsequent packaget or user to warn the ultimate user, if doing so is reasonable. ${ }^{84}$ In cases involving prescription drugs, a categorical rule has cmerged that permits a manufacturer to rely on the prescribing physician to warn the patient. ${ }^{.5}$ Additionally, some courts have permitted component part manufacturers to rely on purchasers to incorporate safety devices when doing so would be impracticable for the component part manufacturer and the purchaser is reasonably reliable. ${ }^{36}$ Although the analysis in these cases is not couched in terms of negligence, it does reflect negligence's reliance on reasonableness, because it balances the costs and benefits of relying on someone else to make the warning or provide a safety feature. Several courts speak as if these decisions have been teduced to a rule-especially in cases involving the learned intermediary doctrine-but some other courts decide duty issues "as a matter of law" in negligence cases. The analysis is sufficiently close to the "reasonableness" inquiry in negligence to create no real difference between negligence and strict products liability.

Other courts, however, take a very different approach. Instead of asking whether the manufacturer acted reasonably, these courts ask whether the product underwent substantial change between the manufacturer and the ultimate consumer. Section $402 \mathrm{~A}$ says that it applies only to cases in which the product is likely to and does reach the ultimate consumer without substantial change. Thus, a seller of raw materials or component parts might escape liability if its own product underwent substantial change before it reached the ultimate consumer, even though a safety improvement or warning by the seller would have been cost justified. ${ }^{87}$

A common issue in these cases is precisely what constitutes a "substantial change."188 But a more serious problem is why "substantial change" should be the test of whether a seller should have responsibility for safety features or warnings. And more to the current point, why should courts address this issue differently in strict products liability - using "substantial change"-than in negligence-using "reasonableness"?

\footnotetext{
84 See, e.g., Goodbar, 591 F. Supp. at 557; see aiso Restatement (Second) Of Torts $\S 388 \mathrm{cmt}$. n (1964). If such reliance is unreasonable - laking into account the difficulty tacing the manufacturer, the level of danger to the ultimate user, and the reliability of the intermediary - the manufacturer cannot rely on the intermediary. See Oman v. Johns-Manville Corp., 764 F.2d 224 (4th Cir.), cert. denied, 474 U.S. 970 (1985).

${ }^{85}$ See, e.g., Bacardi, 442 A.2d 617.

${ }^{30}$ See, e.g., Verge v. Ford Motor Co., 581 F.2d 384 (3d Cir. 1978).

${ }^{87}$ See. e.g. Walker v. Stauffer Chem. Corp., 96 Cal. Rptr. 803 (Cal. Ct. App. 1971); Shawver v. Roberts Corp., 280 N.W.2d 226 (Wis. 1979); see also Union Supply Co. v. Pust, 583 P.2d 276 (Colo. 1978) (holding component part manufacturer liable, but using a "substantial change" analysis). See generally Robert T. Ebert, Comment, Substantial Change: Alteration of a Product as a Bar to a Manufacturer's Strict Liability, 80 Dick. L. Rev. 245 (1976).

${ }^{88}$ See generally Southwire Co. v. Beloit E. Corp., 370 F. Supp. 842 (E.D. Pa. 1974); Restatement (Second) of Torts $\$ 402 \mathrm{~A} \mathrm{cmt.} \mathrm{p} \mathrm{(1964).} \mathrm{Compare} \mathrm{Waker,} 96 \mathrm{Cal}$. Rptr. 803 (transformation of bulk sulfuric acid to drain cleaner substantial) with States S.S. Co. v. Stone Manganese Marine Ltd., 371 F. Supp. 500 (D.N.J. 1973) (transformation of metal alloy into propellers not substantial).

sg Of course, courts could define "substantial" to reflect judgments about "reasonableness," but then they should abandon the claim that they are applying a different standard.Product alteration can also affect the issue of proximate causation. See infra notes $92-104$ and accompanying text.
} 
articulated policies underlying strict products liability do not justify distinguishing between strict products liability and negligence on this issue.

The root of this problem, again, is that courts think of strict products liability as a "separate" cause of action. Consequently, negligence concepts, such as "duty," are "foreign" to strict products liability, ${ }^{90}$ and the courts must develop new standards. On the issue of delegability, the "substantial change" language in section 402A exacerbates this process. But even though courts have come to think of strict products liability as being different, no plausible principle justifies treating a manufacturer's reliance on others for warnings or safety features differently under negligence than under strict products liability. ${ }^{91}$

\section{B.Legal Cause}

The law of legal causation is notorious as a difficult and complex body of material. My purpose is not to examine it in detail, but rather to ask whether the basic test of legal causation should be different in strict products liability than in negligence.

Negligence law traditionally has called legal cause "proximate cause." Its backbone is foreseeability under the "risk rule." "Very roughly, a defendant is liable under this test if the plaintiff's injury was the type of foreseeable injury that made us call the defendant's conduct negligent in the first place. By defining the scope of liability according to foreseeability, the risk rule mirrors the underlying basis of liability in negligence, which holds defendants responsible only for reasonably foreseeable risks. ${ }^{93}$

Applying the risk rule to strict products liability creates some problems. A reason for using foreseeability to define proximate causation in negligence is that foreseeability is

\footnotetext{
90 See Union Supply Co., 583 P.2d at 283.

${ }^{91}$ Alm v. Aluminum Co. of Am., 785 S.W.2d 137 (Tex. 1990), provides an interesting twist to this problem. In Alm, a distinction bom in the cradie of strict tort liablity came full circle to pollute an action for negligence. The plaintiff was injured when a cap blew off a Sevenmup bottle and hit him in the eye. He sued Alcoa, who had manufactured the machine that put the cap on the offending bottle. His theory was that Alcoa was negligent for not warning consumers about this risk. Alcoa responded that it could not practicably warn consumers because it did not actually convey bottles to consumers. Only Seven-Up. who controlled the label, could do so practicably, and Alcoa had wamed Sevenmup. The court agreed that Alcoa could fuffill its duty by waming an intermediary in the "chain of distribution." But Seven-Up was not technically in the chain of distribution because it was not the bottler. Seven-Up had merely licensed the bottler to bottle the soft drink, and Alcoa had sold the capping machine to the bottler. Consequently. Alcoa's efforts to wam Seven-Up were irrelevant (even on the issues of gross negligence and punitive damages). The court's analysis is deficient. The ultimate question in negligence is whether the defendant acted reasonably under the circumstances. Alcoa's warnings to Seven-Up were at least relevant on that issue. But the court got caught up to terminology of strict products liability, terminology that caused it to ask a hypertechnical question about whether the intermediary was in the "chain of distribution." Such a technical analysis should be inappropriate even in strict tort liability, but it is clearly inappropriate in negligence. Thus, the pernicious effect of distinguishing between negigence and strict tort liability came full circle in A1m to infect even a negligence analysis.

${ }^{82}$ See, e.g., Overseas Tankship (U.K.) Ltd. v. Morts Dock \& Eng'g Co. (Wagon Mound I), 1961 App. Cas. 388 (P.C.). A few courts reject the "risk rule" and apply the directness test. See, e.g., Pfeifer v. Standard Gateway Theater, 55 N.W.2d 29 (Wis. 1952).

sa The basic test of foreseeability is altered somewhat even in negligence cases. For example, under the "mechanism rule" the details of the plaintiff's injury need not be foreseeable, only the type of injury. See e.g., Hughes v. Lord Advocate, 1963 App. Cas. 837 (H.L.). Moreover, under the "extent rule" or "eggshell skull rule," the defendant need not foresee the full extent of the plaintiff's injury, only that some injury of that type would occur. See, e.g., Steinhauser v. Hertz Corp., $42 \uparrow$ F.2d 1169 (2d Cir. 1970).
} 
the central element of the underlying standard of liability. But when strict products liability uses a hindsight test to define defectiveness, foreseeability as a test for legal causation would be jarring. It would be a Pyrrhic victory for a plaintiff to win on the issue of defectiveness, even though the product's risks were unforeseeable, if the unforeseeability of the plaintiff's injury defeated legal causation. In this fashion, it makes sense to have a different standard of legal causation in strict products liability than in negligence, at least when strict products liability eschews foreseeability as the underlying test of liability.

Recognizing this problem, courts have grappled with legal causation in strict products liability. Some courts have rejected the nomenclature of "proximate" catusation, preferring instead some other term, such as "producing" causation, to renind them that strict products liability calls for an analysis that eschews foreseeability. ${ }^{94}$ Other courts have used the nomenclature of "proximate" causation, but have asked whether the plaintiff's use of the product, not the plaintiff's injury, was foreseeable. ${ }^{95}$ Most have stayed with the proximate cause terminology and have purported to base proximate causation on foreseeability of result, though they have not explained how this can be reconciled with hindsight as a test of defectiveness in a case where the result was the same one that made the product defective. ${ }^{96}$

The different standard of defectiveness does support a different standard of legal causation in strict products liability, but maintaining a separate standard of legal causation. for strict products liability exacts a high price. If courts abandon negligence precedents, they must develop a new theory of proximate causation for strict products liability.

One tempting solution is to conclude that, by eliminating the requirement of foreseeability, only cause-in-fact remains. In fact, many practicing lawyers assume that this is true. Further reffection, however, reveals that legal causation in strict products liability must be more limiting than cause-in-fact. Consider a defective automobile battery that causes its owner to take the car to the garage. Because of this inconvenience, the owner stays in town rather than going on a weekend trip. Because the owner stays in town, he attends a movie in a theater that burns down, and he is injured. The defective battery was clearly a cause-in-fact of the injury, but surely the injury is too attenuated to permit recovery from the battery manufacturer.

Thus, courts that eschew the negligence approach to legal causation for strict products liability ultimately will be required to construct an alternative approach. This is likely to be a slow process. By its very nature, legal causation is a body of law about unusual accidents. Because it deals intrinsically with unusual results, cases requiring courts to address legal causation are not common. Nevertheless, at some point courts must develop

\footnotetext{
${ }^{94}$ See General Motors Corp. v. Hopkins, 548 S.W.2d 344, 351 n.3 (Tex. 1977). A question remains whether "producing causation" is applicable to strict tort liability cases involving warnings, which do rely on foreseeability to define defectiveness.

${ }_{95}$ See Baker v. International Harvester Co., 660 S.W.20 21 (Mo. Ct. App. 1983).

${ }^{96}$ See Bigbee v. Pacific Tel. \& Tel. Co., 665 P.2d 947 (Cal. 1983) (en banc).
} 
a theory of legal causation that limits the scope of liability in strict products liability cases. Otherwise, they will not be able to avoid incredible results. ${ }^{97}$

One possibility would be to continue to use foreseeability except when it conflicts directly with the hindsight test of defectiveness. Thus, courts could use foreseeability to define proximate causation in cases involving warnings, in cases involving intervening human causes, ${ }^{58}$ and in cases asking whether the plaintiff is a person within the scope of liability. ${ }^{99}$ It is necessary to eschew foreseeability as the test of legal causation only when the plaintiff suffered an injury due to an unforeseeable risk that the court used to evaluate the product as defective under a hindsight approach. This solution would permit courts to rely on the precedents developed in negligence cases to decide most legal causation issues in strict liability. It still would leave the unforeseeable risk case unresolved, however, for which courts would need to adopt a new set of principles.

A solution to this remaining issue could be to use an altered version of the risk rule. Courts use foreseeability to define proximate cause in negligence because only foreseeable tisks count to determine whether a defendant's conduct was negligent in the first place. Courts could adapt a similar analysis to the hindsight test of defectiveness by identifying the risks that we now use to determine that the product is defective and then asking whether the plaintiff's injury was one of those risks. 'This approach would be consistent with the hindsight approach to defectiveness, but it still would offer a significant limitation on the scope of liability in strict products liability. ${ }^{100}$ However, courts have not developed such an approach.

The absence of a well-developed approach to proximate causation has created confusion, which a recent case exemplifies. In Colvin v. Red Steel Co. ${ }^{101}$ the plaintiff was injured when he lost his balance and fell at a construction site. As he was losing his balance, he reached for an unattached I-beam, thinking it was sufficiently massive to support him. In fact, the I-beam was shorter and therefore less massive than prescribed by the specifications. Consequently, it failed to support him, and he fell. The plaintiff argued that the I-beam had a manufacturing defect because it did not meet specifications. The court held for the defendant. The court might have based its holding on an absence of legal causation. Even using hindsight, the risk of a worker falling was not part of the risk that made us call the product defective in the first place. But the court did not rely on legal causation, mainly because previously it had eschewed "proximate" causation in favor of "producing" causation. ${ }^{102}$ Writing on a clean slate, the court had no guidance.

\footnotetext{
${ }^{97}$ For an excellent general discussion of this problem, see David A. Fischer, Products Liability-Proximate Cause. Intervening Cause, and Duty, 52 Mo. L. Rev. 547 (1987).

98 See Ventricelli v. Kinney Sys. Rent A Car, Inc., 383 N.E.2d 1149 (N.Y. 1978).

${ }^{99}$ See. e.g., Pierce v. Hobart Corp., 159 III. App. 3d 31, 512 N.E.2d 14, 111 lll Dec. 110 (1st Dist. 1987).

${ }^{100}$ For example, being burned in a theater is not a risk, even in hindsight, that would make us call an automobile battery defective. On the other hand, risk of toxic shock syndrome is a risk that makes us call superabsorbent tampons defective, even though this risk was unforeseeable when they were first sold. Thus, toxic shock syndrome would, under this approach, be within the scope of legal causation.

101682 S.W.2d 243 (Tex. 1984).

${ }^{102}$ General Motors Corp. v. Hopkins, 548 S.W.2d 344, 35 †. 3 (Tex. 1977).
} 
Instead of honing "producing" causation as a device to resolve unusual accidents, the court held that the I-beam was not defective for this purpose.

"For this purpose" is simply another way of saying that the result was not within the scope of liability. But this approach to defectiveness has no support. Under any standard approach to defectiveness, the I-beam was clearly defective. The "for this purpose"language was doing the work that proximate causation would perform in negligence. But because the court was fearful that proximate causation was a "negligence" concept, it was afraid to refer to it in strict products liability, which is a "separate" cause of action. The point is not that the court reached an incorrect tesult. It is that the court needed to grope for a solution because it could not rely on a rich body of precedents addressing unusual accidents in negligence. This is a cost of having courts write on a clean slate. ${ }^{103}$

The point here is practical as well as theoretical. It is possible to develop an approach to proximate causation that is consistent with the hindsight test of defectiveness, but doing so is a difficult intellectual task. Given the difficulty of developing legal causation for negligence, one wonders whether it is desirable to free courts to repeat the process for strict products liability. Moreover, different approaches to unusual accidents in strict products liability and negligence invites litigants to ask why they were treated differently, merely because their causes of action had different labels. If good reasons existed for treating product cases differently, this would not be a problem. But good reasons do not exist. ${ }^{104}$

\section{Victim Conduct Defenses}

From the beginning of strict products liability, courts have struggled with victim conduct. At the beginning, the main issue was whether contributory negligence should be a defense to strict products liability. Courts' general antipathy toward contributory negligence as an absolute bar to tecovery, even in negligence, certainly affected their attitudes about the defense in strict products liability. In fact, the ability to write on a new slate about contributory negligence may have been a powerful reason for adopting a

\footnotetext{
${ }_{103}$ Fitgerald Marine Sales v. Leunes, 659 S.W.2d 917 (Tex. Ct. App. 1983, writ dismissed 1984), is similar to Colvin. The plaintiff was thrown from a speed boat when the plastic steering wheel he was holding broke. The plaintiff claimed that the steering wheel was flawed because it had voids in the plastic that, presumably, violated the manufacturer's own specifications. The court could have held that the product was defective but that there was no proximate (or producing) causation. This was not the type of risk that made us call the product defective, even from a perspective of hindsight. But as the court did in Colvin, this court denied liability on the ground that the product was not defective for this purpose. This approach raises the same problems as were raised by Colvin, and again the culprit is the fact the courts can write on a clean slate to develop a body of law for unusual accidents.

${ }^{104}$ The absence of a well-developed approach to proximate causation in strict tort liability has also created problems in two other types of "unusual" accident cases. First, an accident might be unusual because the plaintiff used the product in an unforeseeable way. Sometimes such conduct is contributory negligence, but sometimes it is not. Whether or not it is contributory negligence, courts could evaluate the plaintiff's conduct as an intervening human cause under proximate causation. But without a well-cieveloped approach to proximate causation, courts have developed a "defense" of misuse. This has itself created problems, which the next subpart discusses. Second, the plaintiff or a third party might alter a product after the defendant soid it. Again, a well-developed approach to proximate causation could address this issue as one of an intervening human cause. Without such an approach, however, couris have treated product aiteration as an independent issue. I addressed product alteration in notes $92-103$ supra, and accompanying text.
} 
"separate" cause of action in the first place. Comparative negligence reduces this motivation. Thus, it may be easier now to abandon strict products liability than it would have been to refuse to adopt it in the $1960 \mathrm{~s}$.

\section{Comment $n$}

Comment $n$ to section $402 \mathrm{~A}$ suggests a resolution for some issues about defenses, but it leaves other issues open. It reads:

Contributory negligence. Since the liability with which this Section deals is not based upon negligence of the seller, but is strict liability, the rule applied to strict liability cases (\$524) applies. Contributory negligence of the plaintiff is not a defense when such negligence consists merely in a failute to discover the defect in the product, or to guard against the possibility of its existence. On the other hand, the form of contributory negligence which consists of involuntarily and unreasonably proceeding to encounter a known danger, and commonly passes under the name of assumption of risk, is a defense under this Section as in other cases of strict liability. If the user or consumer discovers the defect and is aware of the danger, and nevertheless proceeds unreasonably to make use of the product and is injured by it, he is barred from recovery. ${ }^{105}$

This language purports to resolve two of three possible situations.

At one end of the spectium, the plaintiff's conduct is no more than a mere failure to discover or guard against a defect. This type of conduct does not count at all against a plaintiff. In effect, the plaintiff does not have a duty to inspect for or worry about product defects.

At the other end of the spectrum, the plaintiff knows about a risk and unreasonably proceeds anyway. This conduct constitutes assumption of risk and bars recovery (or after the advent of comparative negligence reduces recovery). Comment $\mathrm{n}$, however, does not resolve the middle of the spectrum. Comment $\mathrm{n}$ is silent about independent contributory negligence, i.e., conduct thar is more than a mere failure to discover or guard against a defect but does not rise to the level of assumption of risk. Drunk driving is an example. ${ }^{106}$

Courts have varied in their use of comment $\mathrm{n}$. Some early decisions interpreted comment $n$ to exculpate all forms of contributoty negligence from strict products liability, not just a mere failure to discover or guard against a defect. ${ }^{107}$ Others count independent contributory negligence against a plaintiff as long as it is more than a mere failure to discover or guard against a defect. ${ }^{108}$ Still others wisely ignore comment $n$ and count all types of contributory negligence in strict products liability, just as they would do in negligence. ${ }^{109}$ Counting contributory negligence against a plaintiff has become increasingly common after the advent of comparative negligence.

\footnotetext{
\$c5 Restatement (Second) of Torts $\$ 402 \mathrm{~A} \mathrm{cmt.} n$ (1964).

${ }^{106}$ See Daly v. General Motors Corp., 575 P.2d 1162 (Cal, 1978).

107 See. e.g., McCown v. International Harvester Co., 342 A.2d 381 (Pa. 1975).

108 See e.g., West v. Caterpillar Tractor Co., Inc., 336 So. 2d 80, 92 (Fla. 1976); Busch v. Busch Constr. Inc., 262 N.W.2d 377, 394 (Minn. 1977).

${ }^{109}$ See, e.g., Sandford v. Chevrolet Div, of General Motors Corp., 642 P.2d 624 (Or. 1982).
} 
By distinguishing among three types of consumer conduct, comment $n$ creates issues about precisely when a case falls into one type or another. At one end of the spectrum, how does one define contributory negligence that is no more than a mere failure to discover or guard against a product defect? For example, in Houston Lighting 8 Power Co. $v$. Reynolds ${ }^{110}$ the plaintiff was electrocuted when he strung eight tent poles together to touch an overhead electric distribution line. He sued the utility under strict products liability for failing to warn the public about the risk of touching overhead lines. When the utility responded that the plaintiff was contributory negligent, the plaintiff argued that his conduct was no more than a mere failure to discover or guard against the product defect, i.e., the danger of electricity and the utility's failure to warn. The court of appeals agreed with the plaintiff.

Would the court have reached a similar conclusion if a drunk driver was unaware of a defect in a car that he negligently drove off the road? It is not a distinction that the driver knew that drunk driving involved some risks, because surely Reynolds knew touching an overhead line involved some danger, even if he did not understand the full extent of the specific danger. Inculpating only those who understand the full extent of the specific danger and the existence of a defect is tantamount to requiring assumption of risk, and it thereby eliminates independent contributory negligence as a defense. But just where a plaintiff's ignorance about the product becomes more than a mere failure to discover or guard against a risk is unclear.

At the other end of the spectrum, what precisely constitutes knowledge of a defect? The third sentence of comment $n$ suggests that the plaintiff only needs to know about the risk and proceed unreasonably. The fourth sentence suggests that the plaintiff must actually discover the defect and proceed unreasonably. As Reynolds demonstrates, these two states of mind are not equivalent: the plaintiff might have known about the risk of electrocution without being aware that the utility had failed to warn against it. But nothing in conment $n$ or its history suggests that the drafters intended to draw a distinction here. $^{111}$

Nothing in the logic of strict products liability requires this confusion. Courts can avoid it with careful analysis. But by making a new set of distinctions not made in

110712 S.W.2d 761 (Tex. Ct. App. 1986), rev'd, 765 S.W.2d 784 (Tex. 1988).

is Keen v. Aahot Ashkelon Ltd., 748 S.W.2d 91 (Tex. 1988), is another case that demonstrates the difficulty of distinguishing among these three types of plaintiff conduct. The plaintiff parked his trailer next to a trailer that was being unloaded. Doing so was in violation of a well known safety rule. The trailer being unloaded tipped over and injured the plaintiff. It did so because it had a defective "sandshoe," which supported the trailer when it was not attached to the tractor. The defendant argued that the plaintiff was contributory negligent, but the court held that the plaintiff 's conduct did not count, because it did not rise to the level of assumption of risk. This was so because the plaintiff was not aware of the defect in the sandshoe. The plaintiff was, however, aware of the risk that trailers being unloaded can tip over. Arguably, the plaintiff's conduct was more than a mere failure to discover or guard against a defect. It was negligence independent of the defect. Nevertheless, the court ruled that it did not count, even though in an earlier case, the court held that independent contributory negligence does count against a plaintiff in strict tort liability. See Duncan v. Cessna Aircraf́t Carp., 665 S.W.2d 4^4 (Tex. 1984). 
negligence, comment n requires courts to face a new set of issues at the borders, and they must do so without much help from precedents developed in negligence. It is another example of courts being invited to write on a clean slate, with all of the attendant difficulties.

Some voices have been raised to offer reasons for distinguishing between negligence and strict products liability with regard to consumer conduct defenses. For example, dissenting in Daly थ. General Motors ${ }^{12}$ Justice Mosk argued, reflecting the language of comment $\mathrm{n}$, that because strict products liability is not based on the defendant's negligence, it makes no sense to evaluate the plaintifr's negligence. The argument is a non sequitur. Why should the fact that we forgive the plaintiff the burclen of proving the defendant's faul -due to difficulties of proof-cause us to preclude the defendant from even trying to prove that the plaintiff was negligent? In fact, the same problems of proof do not exist for a defendant trying to prove a plaintiff was negligent. Even if they did, why not let the defendant at least try?

Nor do any of the other articulated rationales for strict products liability argue against evaluating the plaintiff's negligence. Even in early cases- - where contributory negligence was an absolute bar and courts had a strong motivation to write on a clean slate - no good analytical reasons existed for distinguishing between strict products liability and negligence. The advent of comparative negligence undermined even the psychological motivation for purging contributory negligence from strict products liability, and the absence of good analytical reasons to distinguish between the two causes of action persists. ${ }^{113}$ Some proponents of the distinction have argued that it is impossible to compare the fault of the plaintiff with the culpability of a strict products liability defendant.

See, e.g., id. (Jefferson, J., concuming and dissenting). Making such a comparison, proponents argue, would be like comparing apples with oranges. Jurors might assign percentages to each party, but they must do so arbitratily.

\footnotetext{
${ }_{1 \text { 12 }} 575$ P.2d 1162 (Cal. 1978). This argument is not persuasive. We routinely compare apples and oranges, either by focusing on a shared feature or referring to an overarching value system. A common feature of negligence and strict tort liability is risk-utility imbalance. An overarching value system is an amalgam of the reasons for and against recovery. We often allocate resources by balancing apparently incommensurate values. For example, we balance the competing needs of national defense and social programs without conflating the competing considerations. Even though the arguments for strengthening national defense differ from the arguments for mitigating poverty, referring to an overarching conception of a good society, based on some value like fairness or utility makes them commensurable. On a personal level, we similarly make a choice between taking a vacation and buying a new car. The overarching values involved in these decisions may be vague and controversial, but we commoniy choose among competing alternatives as though we can refer to those values. See generally The Persistence of Fault, supra note 5 , at 802-05. As a practical matter, jurors may have difficulty understanding the complex factors involved in a decision about liability and making a comparison that is not based solely on fault. An attractive aspect of negligence generally, and of comparative negligence specifically, is that is turns on values with which jurors are likely to be familiar. Indeed, the likely persistence of fault in jurors" minds should tell us something about theories that eschew fault. Abandoning strict tort liability as a "saparate" cause of action would have the advantage of having cases turn on values with which jurors are familiar, and it would eliminate the perceived problem of comparing apples and oranges.
} 
Reynolds exemplifies the arbitrariness of having different defenses applicable to strict products liability and negligence. The jury assigned fifty percent "fault" to HL\&P and fifty percent fault to the plaintiff. The court of appeals held that strict products liability governed the case and that the plaintiff's negligence was no more than a mere failure to discover or guard against the defect. ${ }^{14}$ Thus, the court permitted the plaintiff to recover all of his damages, not merely fifty percent. The Texas Supreme Court then held that strict products liability did not govern the case. "Thus, the plaintiff's conduct did count against him, even if it was merely a failure to discover or guard against a defect. ${ }^{136}$ A change in nomenclature of the underlying cause of action changed everything, even though the underlying standard of liability for failure to wam is identical in negligence and strict products liability.

\section{Mitigation of Damages and Avoidable Consequences}

Strict products liability also invites courts to write on a clean slate with respect to another issue. Several courts distinguish in negligence among plaintiff conduct that caused an accident (regular contributory negligence), plaintiff conduct before an accident that aggravated the injuries but did not cause the accident (avoidable consequences), and conduct after an accident that aggravated the injuries (mitigation of damages). 17 These distinctions were escape devices from the harshness of contributory neghigence as an absolute bar: They make little sense in a world of comparative negligence, if they ever did.

Regardless of the wisdom of making these distinctions, courts now must determine whether they apply to strict products liability. If they do, courts will need to distinguish among three types of contributory negligence along one axis (defined by comment $n$ ) and three different types of contributory negligence along another axis (defined by this body of law). Such a scheme can become quite confusing. If these courts do not apply these distinctions to strict products liability-but continue to apply them to negligence-then they must justify different treatment that depends on the nomenclature of the underlying cause of action. Again, strict products liability as a "separate" cause of action invites courts to write on a clean slate and grapple with these issues all over again.

\section{Misuse}

Another consumer conduct defense that has caused difficulty in strict products liability is "misuse." Misuse is the term courts use to refer to two different forms of conduct. Sometimes it refers to a plaintiff who discovers a defect and uses the product anyway. At

\footnotetext{
${ }_{114}^{14} 712$ S.W.2d 761 (Tex. Ct. App. 1986).

115765 S.W.2d 784 (Tex. 1988).

${ }_{116}$ in fact, as a negligence case, a special no duty rule for cases involving legally placed overhead distribution lines entitled HL\&P to a take nothing judgment.

See id. at 786 .

117 See, e.g., Carnation Co. v. Wong, 516 S.W.2d 116 (Tex. 1974); Kerby v. Abilene Christian College, 503 S.W.2d 526 (Tex. 1973); Moulton v. Alamo Ambulance Serv., Inc., 414 S.W.2d 444 (Tex. 1967). But see Pool v. Ford Motor Co., 715 S.W.2d 629, 633 (Tex. 1986),
} 
other times, however, misuse refers to an unforeseeable use. ${ }^{118}$ Some courts have stated that misuse is no longer an absolute bar to recovery but causes only a percentage reduction under comparative principles, but it is not clear whether these courts are referring to misuse as a version of assumption of risk or misuse as a lable for an unforeseeable use. ${ }^{119}$

As a version of assumption of risk, misuse is a superfluous doctrine. Even when it refers to an unforeseeable use, misuse need not be an independent doctrine. If the plaintiff's use of the product is truly unforeseeable, it is an unforeseeable intervening human cause, which should defeat proximate causation. But most courts have failed to develop a workable conception of proximate causation to evaluate unusual accidents in strict products liability. ${ }^{120}$ Misuse serves as a surrogate for proximate causation analysis for the limited group of cases in which the plaintiff's use of the product is at issue. Courts could abandon misuse altogether if they would develop proximate causation in strict products liability. This is another issue on which they have created confusion by adopting a different analysis for strict products liability than for negligence. ${ }^{1212121}$ In fact, unforeseeable use might affect the plaintiff's recovery in several ways. First, if a product's only risks occur during unusual uses, the product might not be defective. Second, a plaintiff's unforeseeable use might be an aspect of proximate causation. Third, if a plaintiff's use of a product is unreasonable as well as unforeseeable, it might be contributory negligence. What is clear, however, is that courts could subsume misuse into these other doctrines without it having an independent life of its own. Courts have given it an independent life of its own because they have taken a different approach to plaintiff conduct under strict tort liability than they have under negligence.

\section{D.Problems in Determining Whether a Case Is Governed by Strict Products Liability}

Courts have grappled with the problem of determining what kinds of transactions and defendants strict products liability governs. For example, courts have asked whether strict products liability governs leases, ${ }^{122}$ bailments, ${ }^{123}$ publications, ${ }^{124}$ used products, ${ }^{125}$ real

\footnotetext{
:18 See Perfection Paint \& Color Co. v. Konduris, 258 N.E.2d 681 (ind. App. 1970).

119 See Duncan v. Cessna Aircraft Co., 665 S.W.2d 414 (Tex. 1984).

${ }^{120}$ See supra notes $92-104$ and accompanying text, it may be that courts developed misuse as a defense because they did not believe what they were saying about contributory negligence and proximate causation. A good example is General Motors Corp. v. Hopkins, 548 S.W.2d 344 (Tex. 1977). The plaintiff was injured when his car went out of control. He alleged that a defective accelerator caused the accident. The defendant argued that the plaintiff had replaced his carburetor. The court held that this was product misuse, which constituted a comparative defense. It is not clear what the court meant by "misuse." If seems strange to think that replacing a carburetor was unforeseeable. Moreover, there was no evidence that the plaintiff was actually aware of the defect or the risk, which would trigger the "assumption of risk" version of misuse. The thrust of the defendant's argument was that the plaintiff botched the job, which would be contributory negligence. But Texas courts at that time eschewed contributory negligence and proximate causation in strict tort llability. The court seemed to stretch the concept of misuse to inciude contributory negligence. This obfuscation would not have been necessary had the court simply used standard negligence theory instead of viewing strict tort liability as a "separate" cause of action.

122 See, e.g., Martin v. Ryder Truck Rental, Inc., 353 A.2d 581 (Del. 1976).

${ }^{123}$ See, e.g., Armstrong Rubber Co. v. Urquidez, 570 SW.2d 374 (Tex. 1978).

$\$ 24$ See, e.g. Cardozo v. True, 342 So. $2 d 1053$ (Fla. Dist. Ct. App. 1977).

${ }^{125}$ See, e.g., Tillman v. Vance Equip. Co., 596 P.2d 1299 (Or. 1979).
} 
estate, ${ }^{126}$ and services ${ }^{127}$ Different treatment of collateral doctrines increases the importance of classifying these cases, and classifying them requires time and effort that would not be necessary if strict products liability were not a "separate" cause of action.

Even after a court has decided whether strict products liability applies to broad categories of cases, individual cases will continue to arise in which the court must decide whether the particular transaction fits into the category. For example, even if strict products liability governs bailments, does a shopping cart used at a supermarket qualify as a bailment? ${ }^{\text {:28 }}$ Even if strict products liability does not govern services, is electricity in an overhead distribution line a service or a product? ${ }^{\text {129 }}$ These cases teprise the question whether product cases are meaningfully different from nonproduct cases. ${ }^{130}$ If they are not, courts will have a difficult time drawing lines between the two types of cases, which will drain judicial resources and frustrate parties' expectations. Abandoning the distinction would alleviate this problem.

As I noted above, the different treatment courts give to collateral issues under strict products liability and negligence currently exacerbates this problem. The difference between the two theories on the underlying standard of liability is often unimportant. ${ }^{131}$ Often the issue that turns on a decision about the applicability of strict products liability is not the underlying standard of culpability, but one of the collateral doctrines I have addressed, even though no good reasons exist for treating the collateral doctrine differently under the two theories.

\section{E. Cost of Collateral Doctrines}

Resolving collateral doctrines in strict products liability has required a great deal of judicial energy, and the issues themselves have created a great deal of confusion. They also have been a source of inequality: courts treat different litigants differently on a particular issue solely on the ground that strict products liability does or does not govern the case, even though none of the underlying principles articulated in favor of strict products liability support different treatment. The fact that existing doctrine encourages courts and lawyers to think of strict products liability as a "separate" cause of action exacerbates these problems. Courts would eliminate them if they simply abandoned the distinction between strict products hability and negligence in the first place.

\section{Applying Different Theories to Multiparty Lawsuits}

A final problem of maintaining two distinct theories of liability in personal injury cases is that it can create havoc for courts trying to submit a case to the jury. The problem often occurs

\footnotetext{
${ }^{126}$ See, e.g., Becker v. IRM Corp, 698 P.2d 116 (Cal. 1985).

127 See, e.g., Hoffman v. Simplot Aviation, Inc., 539 P.2d 584 (Idaho 1975).

${ }^{128}$ See Keen v. Dominick's Finer Foods, inc., 49 Ill App. 3d 480, 364 N.E.2d 502, 7 Ill. Dec. 341 (Ist Dist. 1977) (supermarket shopping cart not a baiment).

${ }^{128}$ See, e.g., Houston Lighting \& Power Co.v. Reynolds, 765 S.W.2d 784 (Tex. 1988) (electricity a product). ${ }^{130}$ See supra notes $6-47$ and accompanying text.

131 In warnings cases, the standards are identical. Even in design cases, the difference in underlying standards of liability is often unimportant, at least if the product's risks were reasonably foreseeable when the product was sold.
} 
in cases involving multiple defendants, but it also can be a problem in cases involving multiple claims against a single defendant. ${ }^{132}$

Distinctions between strict products liability and negligence are difficult for lawyers and judges to keep straight. They are impossible for jurors to keep straight. Cases with multiple parties and multiple theories of liability, however, often require jurors to sort out these distinctions. Not only must the jury distinguish between negligence and defectiveness as the underlying standard of liability, it must also learn different definitions of causation, different defenses, and different measures of damage for each theory. Although learning these distinctions is theoretically possible, the effect is a likely source of confusion for the jury.

For example, in strict products liability, several courts do not consider the plaintiff's conduct if it is no more than a mere failure to discover or guard against a defect, but they do consider such conduct in negligence. ${ }^{133}$ Consequently, the jurors might hear evidence and arguments about this type of conduct, only to be told that they should ignore it on one of the plaintiff's claims. Or a court might use a different rule of legal causation in strict products liability and in negligence. ${ }^{134}$ Specifically, a question might atise whether intervening negligence of a doctor negates legal causation. The jury would be required to apply different standards of legal causation to this event under each of the plaintiff's theories of recovery. Similar examples could be drawn from each of the collateral issues addressed in Part IV.

Having different rules govem different parts of a single lawsuit is likely to confuse jutors. Not only must they learn two different standards, they will hear evidence that is relevant under one standard but not relevant under the other. This is likely to be especially confusing if the jurors do not have an intuitive sense of why different rules should govern the different claims. We can expect jurors to absorb and learn only so much information. ${ }^{135}$ Insisting on different rules for strict products liability and negligence increases the amount of the information jurors must assimilate and process. Were it important to draw these distinctions, the effort required to keep the distinctions straight might be worthwhile. But as Part II demonstrates, there is no strong reason to distinguish between strict products liability and negligence in the first place.

The application of comparative principles to multiparty or multitheory litigation exacerbates this problem. On some issues a court must apply a uniform rule to all defendants and all causes of action to make a comparative scheme work. If a court normally applies different rules to different causes of action, it will need to resolve which of the rules governs a multiparty, multitheory case. ${ }^{136}$

For example, a court might have different rules conceming joint and several liability or concerning how much plaintiff culpability is required to bar the plaintiff from recovering. It is

\footnotetext{
${ }_{132}$ Multiparty litigation, such as mass tort litigation, sometimes involves multiple plaintiffs. Although my analysis focuses on more traditional litigation with one plaintiff, the problems it reveals are also applicable to multiplaintiff litigation.

${ }^{133}$ See supra notes $105-21$ and accompanying text.

:34 See supra notes $92-104$ and accompanying text.

:35 See, e.g., Turner v. General Motors Corp., 584 S.W.2d 844 (Tex. 1979).

${ }^{136}$ See, e.g., Duncan v. Cessna Aircraft Co., 665 S.W.2d 414 (Tex. 1984).
} 
procedurally impossible to apply different rules to different causes of action in the same lawsuit. A court cannot make a defendant jointly and severally liable on the products claim but not on the negligence claim. Nor can a court bar a plaintiff from recovery on the negligence clain but not on the products claim. A court must apply common rules to the whole case.

A further problem arises because the court will not know for sure whether a case involves specific theories of liability until after the jury returns its verdict. A court might hold that all cases should be treated as they are pleaded, but this would give the plaintiff total control over the applicable rules. If a court waits until the jury returns its verdict, however, the parties will not know the ground rules until the jury renders its verdict.

For some rules--such as joint and several liability or modified versus pure comparative negligence-awaiting a verdict to ascertain the rule is procedurally workable. The court, after the verdict, applies these rules, and the court can do so after it learns from the verdict what type of case it is addressing. But on other issues-such as plaintiff conduct defenses and causationthe court needs to instruct the jury before it retires. Thus, the court is caught in a Catch 22 : it must instruct the jury before the verdict, but it does not know the appropriate instructions until after the verdict.

For example, some courts hold that a plaintiff's mere failure to discover or guard against a product defect counts against the plaintiff in negligence but not strict products liability. The court must instruct the jury whether to count this conduct in the percentage it assigns to the plaintiff (At an earlier stage of the trial the trial court must also decide whether such evidence is even admissible.) But the court will not know the answer to this question until after the jury comes back with its verdict.

A court could solve this problem by asking the jury to segregate the percentage of negligence it assigns to the plaintiff. The court could ask the jury to assign one percentage for mere failure to guard against a defect and another percentage for other types of contributory negligence. The court could then construct a judgment based upon the appropriate percentages, depending on the causes of action the jury recognized. Suppose the jury found that the plaintiff was $10 \%$ negligent for failing to discover or guard against a defect and $30 \%$ negligent for drunk driving, and that the defendant was $60 \%$ responsible for a defective product. The court could reduce the plaintiff's recovery by $40 \%$ if the case tumed out to be based on negligence, or by only $30 \%$ if it turned out also to be based on strict products liability. ${ }^{137}$

On other issues, however, even a complicated instruction of this sort would be difficult. For example, on the issue of proximate causation, the jury must decide either yes or no. To do so, the court must give it the correct standard. If a different standard governs strict products liability than governs negligence, the court will not know which standard to use when it instructs the jury. So far, the court could solve the problemby asking the jury to decide under both standards and then constructing a judgment depending on whether strict products

${ }^{137}$ To be technically correct, the court should reduce the plaintiff's judgment by $30 / 90$ rather than $30 \%$, because, by definition, the court should ignore the $10 \%$ assigned to the plaintiff's failure to discover the defect. See, e.g., Haney Elec. Co.v. Hurst, 624 S.W.20602 (Tex. Civ. App. 1981). 
liability or negligence governed the case, although such a submission could become extraordinarily complicated.

These problems are more intractable, however, in cases involving multiple defendants, some of whom are governed by strict products liability and some of whom are governed by negligence. In such a case, a jury must compare each defendant with the other defendant(s) and with the plaintiff to assign appropriate percentages. If strict products liability governs one defendant and negligence governs another, and if different rules concerning plaintiff conduct and/or proximate causation govern each defendant, the court will be asking the jury to put different elements into a common comparative scheme. The plaintiff's conduct might count in the comparison against one defendant but not the other: Or under different rules of proximate causation, one defendant might be responsible for a part of the injury for which the other defendant is not responsible. It would not be practicable to assign a single set of percentages for a single set of damages. Even here, it might be theoretically possible in some cases to ask the jury to divide the case according to different units of damage, then apply different sets of percentages to each unit. ${ }^{138}$ But all of this would be extraordinarily complicated.

These problems reveal an underlying tension between comparative principles and the distinction between strict products liablity and negligence. The crux of comparative principles is that different contributions to an injury are, by and large, comparable because they are part of a unified personal injury. The distinction between strict products liability and negligence cuts in just the opposite direction, however. This point is a twist on the complaint about trying to compare apples and oranges when applying comparative negligence to strict products liability. ${ }^{139}$ Although it is possible to compare apples and oranges, doing so requires sophistication that creates difficulties of its own. It is always easier to compare apples with apples. Comparative schemes work better when the units of comparison are similar; they work more poorly when the units of comparison are different. The distinction between strict products liability and negligence has the effect of throwing sand into the cogs of the comparative machine. Courts could avoid all of this by abandoning the distinction between strict products liability and negligence.

\section{Conclusion}

A proposal to abandon strict products liability appears to be dramatic. In fact, it is not. The reasons supporting strict liability as a special system for product cases are weak. Maintaining the distinction between strict products liability and negligence has a pernicious effect on personal injury litigation. Moreover, abandoning the distinction would not be dramatic as a practical matter. Although the "theory of liability" and its accompanying jury instructions can have a psychological impact on jurors, few worthy product cases today could not be brought

\footnotetext{
${ }^{138}$ For example, the jury could be asked to segregate damages caused by the defendanis under the product standard and the negligence standard of proximate causation and then assign percentages for each defendant who caused each portion of the damage. This would in effect, treat the case as though it involved two separate injuries.

139 See supra note 112 .
} 
successfully under negligence. The only significant distinction in cases other than manufacturing defects is whether a risk was foreseeable, and in many product cases foreseeability of risk is not an issue. We can abandon the distinction with little impact on worthy cases. Doing so would have a beneficial impact on the administration of justice. 